\title{
Courts and Pharmaceutical Patents: From Formalist Positivism to the Emergence of a Global Law
}

\author{
Calixto Salomão Filho and Vitor Henrique Pinto Ido
}

\begin{abstract}
This article seeks to repurpose the relation between courts and IP law, avoiding describing them as a purely neutral and unidimensional process whereby 'courts apply IP law'. Based on two cases from Brazil (Trastuzumab and Sofosbuvir), the article argues that the role of courts in implementing TRIPS flexibilities is in itself a factor that determines or at least influences the behavior of actors in the field. As such, courts are not arenas, but actors that influence competition and restructure markets. This pushes for the recognition that patent use and patent abuse, including practices in patent filings such as evergreening and sham litigation, are legal phenomena that ought to be regulated differently by law. Instead of formalist positivism, law should be more thoughtful of socio-economic consequences and of existing contexts. This aims at addressing economic structures rather than reinforcing them in cases pertaining to pharmaceutical patents.

The article concludes by proposing an interpretation of IP law which is integrated with competition law principles, both oriented towards, and based on, public interest provisions. Overall, the article posits that this is a better framework than regarding IP and competition law as 'complementary' and to address issues of how courts may be misused by economic actors due to fragmentation of the two legal fields. Furthermore, such endeavors are part of an emerging body of what some could even call "global law"; in this case, it means a nod for the transnational implications of national IP cases beyond its original realm.
\end{abstract}

\footnotetext{
C. S. Filho $(\bowtie) \cdot$ V. H. P. Ido

Faculty of Law, University of São Paulo, São Paulo, Brazil

South Centre, Geneva, Switzerland

(C) The Author(s) 2022 


\section{Introduction}

Courts are prominent actors in the implementation of intellectual property (IP) law. ${ }^{1}$ Apart from being enforcers of the existing law, they also delineate the contours of IP protection, including the definition of patentability criteria, scope of protection of IPRs, exclusions of patentable subject and conditions for enactment of injunctions. ${ }^{2}$ This is an intrinsic characteristic of how IP law is conceived and how it operates, rather than a process of politicization of courts or an expansion of their role beyond their competence. ${ }^{3}$ By doing so, courts inevitably affect competition and play a major role in the implementation of TRIPS in national jurisdictions, often with transnational consequences.

Scholarship's attention on the role of judicial and quasi-judicial courts in IP has risen, ${ }^{4}$ including advocates for courts to be the best suited for balancing IP policies ${ }^{5}$ and ample discussions on specialized IP courts. ${ }^{6}$ Judicial enforcement of IP has become a common, yet very questionable, variable for assessing what is understood as the level of IP protection in a given country. ${ }^{7}$ It has also deserved emerging

\footnotetext{
${ }^{1}$ While judges in some jurisdictions may be typically more prominent in such role-such as common law systems, which give more importance on precedents-, the last decades saw an unquestionable rise in the number of courts dealing with IP. This process has both a geographical dimension and an institutional one. Geographically, there has been a "globalization" of jurisdictions deciding upon IP and pharmaceutical cases. Institutionally, there has been a stark expansion of actors deciding IP cases, such as quasi-judicial independent IP appellate bodies, competition authorities' decisions and IP specialized courts.

${ }^{2}$ They are not the only relevant actors, as administrative border agents, police officers and others all concretely decide on issues such as what is a counterfeit. Nonetheless, courts have a specifically defining role as they provide the basis for the applicability of laws and regulations "on the ground".

${ }^{3}$ In this sense, when adjudicating IP cases, judges do not create, but rather apply, law. The issue is that this process is by default not a mere formalistic endeavor, and the exact details of IP law necessarily depend upon such interpretation. In many jurisdictions, where public considerations are directly embedded into IP law, this adjudication cannot be dissociated from a broader spectrum of public principles, including health and socio-economic development. Acknowledging this particular feature of IP law is not the same as advocating for courts to disregard precedents, decide against the law or over-expanding their own competence. As this paper will point out in more detail, the refusal to acknowledge such role, including when courts do not rule, is in itself a factor that impacts competition, generates judicial uncertainty and compromises the whole IP system. Also please see Sect. 2 of this article for a more comprehensive argument on the role of courts in IP.

${ }^{4}$ For a comprehensive overview of developed countries, see Geiger et al. (2018).

${ }^{5}$ Burk and Lemley (2013) (on the specific case of the USA, acknowledging its failures and considering that courts are the most suitable for patent law reform by adopting different interpretations according to different industries).

${ }^{6}$ de Werra (2016). Published in: Specialised Intellectual Property Courts - Issues and Challenges, Global Perspectives for the Intellectual Property System, Issue Number 2: CEIPI-ICTSD. 2016, p. 15-41. Available at SSRN: https://ssrn.com/abstract=2761209 (drawing positive and negative arguments for their implementation, noting that they cannot be recommended in all circumstances).

${ }^{7}$ In those cases, "judicial enforcement" simply means the enforcement of pro-IP holder interests, without the inclusion of public interest provisions. As such, these rankings may wrongly give the impression that enforcement of IP means exclusively the protection of private rights. It is not a
} 
importance by the WIPO, the South Centre and other international organizations as key players in implementing IP norms, each with a distinct approach. ${ }^{8}$

In particular, the consequences of court rulings to access to medicines is a sensitive topic, particularly if decisions are taken prioritizing exclusively IP holder interests. A single court ruling (or sometimes lack thereof) may have huge consequences for public policies and the realization of rights, as IPRs may pose major barriers to competition and access to essential products. As such, it makes sense to craft a more comprehensive analysis of the role of courts in implementing or not the in-built TRIPS flexibilities ${ }^{9}$ across jurisdictions.

This article seeks to repurpose the relation between courts and IP law, avoiding describing them as a purely neutral and unidimensional process whereby 'courts apply IP law'. According to this view, the main issue of concern would be how to provide specific technical knowledge on IP for judges. Instead, this article aims at exposing that jurisdictional practices are themselves an element to interpret TRIPS flexibilities, as courts reshape markets and the extension of patent monopolies even when they decide not to take action. In this sense, courts apply IP and by doing so define markets; they are also mutually influenced by the market structures.

surprise that they are used as pressure tools for developing countries to adopt more stringent standards of protection. In reality, the process of enforcement is supposed to be a balancing between private and public interests and should be seen as an important policy space for countries to enact IP policies that are coherent with other goals such as public health and industrial development (see Li and Correa (2009). For the use of rankings, see, for instance, "create", the U.S. Chamber International IP Index, which includes numerous indicators on enforcement. The 2018 edition included new indicators, which "cover important evolving areas of IP rights, such as injunctive-style relief through the disabling of infringing content online, as well as the practical operation of a given national IP system. As the Index evolves, it is only natural that a greater focus be placed on the operational aspects of a national IP system. The new indicators seek to measure national efforts at coordinating IP rights enforcement", among others (https://www.theglobalipcenter.com/wpcontent/uploads/2018/02/GIPC_IP_Index_2018.pdf). Similarly, the International Property Rights Index (associated to the Property Rights Alliance, an explicitly pro-property organization) includes indicators such as "judicial independence", "rule of law", "protection of intellectual property rights" and "perception of IP protection" (https://www.internationalpropertyrightsindex.org/about). These rankings also find a notable echo in older and criticizable views of the "Law and Finance literature", which evaluated jurisdictions according to their capacity to secure private rights (See La Porta et al. (1998), pp. 1113-155).

${ }^{8}$ The World Intellectual Property Organization (WIPO), for instance, has created its WIPO Judicial Institute (https://www.wipo.int/about-wipo/en/activities_by_unit/index.jsp?id=1022). Technical assistance provided by many multilateral institutions, including the European Patent Office (EPO), the European Commission, the United States Patent and Trademark Office (USPTO) and the JPO (Japanese Patent Office) have reportedly increased attention to judges, offering trainings that often mirror their understandings of IP law to other jurisdictions. An example is the internationalization of doctrines that are originally European, such as the "Swiss claims" or the need to protect "Markush claims" for pharmaceuticals. Other institutions seek an alternative approach, such as the South Centre, which focuses its activities on the full implementation of TRIPS flexibilities in relation to IP law (https://ipaccessmeds.southcentre.int/).

${ }^{9}$ For an overview of the notion of TRIPS flexibilities and their implementation, see Correa (2016); see also Deere (2008). 
Furthermore, other actors play crucial roles, including civil society organizations and lobbying economic pressures, ${ }^{10}$ and dealing with them is another important dimension of the role of courts. In summary, it means a broader understanding of their role, which is embedded in certain structures of thinking and socio-economic implications and pressures. As we wish to propose, this framework allows a different legal assessment of what in practice courts do and what economic consequences their own behavior bear. For instance, when a court does not rule or takes too long to rule an IP case, this in itself likely generates more judicial uncertainty than the content of the decision. Despite differences in how this understanding reverberates in concrete IP cases, a general takeaway is that this requires a different interpretation of IP law, as per below.

The structure of the article is as follows: after this overview, it provides some inputs for the reasons why courts, while implementing TRIPS flexibilities, can be considered to be channels of "structural change". This serves as a theoretical premise to the analysis. It is followed by an assessment of the consequences of the legal utilization - both directly and indirectly_ of a narrative that treats intellectual property protection as necessary for innovation. ${ }^{11}$ This normative argument serves as a de facto tool for impeding evidence-based discussions on the competitive implications of IP in concrete cases. In short, the threat of decreased innovation is used, even if sometimes implicitly, to impede a more balanced and real consideration of rights and interests involved in IP law.

It then exemplifies the overall argument above through the comparison of two cases in Brazil. They share the similarity of dealing with access to medicines curbed by high prices (due to, among other reasons, intellectual property rights), albeit with different profiles, courts and arguments. In both, the role of courts is paramount, not only as the ones defining the interpretation of legal principles and rules in IP law with regards to demands of access to medicines, but also as setters of expectations for competitors and society at large. Both medicines have been subject to patent disputes in the country, in a way that IP is not necessarily the only issue to be considered, but certainly a relevant one. The first case refers to a litigation that questioned prices on the selling of cancer biological medicine Trastuzumab to Brazilian public entities, particularly in light of a stark price discrimination between regular public purchases

\footnotetext{
${ }^{10}$ The number of institutions, arenas and players engaging with the topic of IP has grown immensely since the TRIPS Agreement was enacted. In the IP and public health field, key actors include civil society organizations (such as Médécins sans Frontières-MSF Access Campaign) and industry representatives (International Federation of Pharmaceutical Manufacturers \& Associations-IFPMA). New organizations (such as the Medicines Patent Pool-MPP) have been created and also shape and influence the very interpretation and implementation of IP. The existing framework of global IP law and access to medicines is in many senses dependent on the work of these organizations. See Hein and Moon (2013) and Matthews (2011).

${ }^{11}$ While the specialized literature has a lot of divergence, the transplantation of this discussion into a legal argument in IP cases tends to over-expand the scope of protection of patents in particular. Therefore, by shedding light on the possibility of another kind of relation, that of innovation that arises precisely from more access (to knowledge), and not from more monopolies (patents and other IPRs), it is possible to reassess the role of IP in legal rulings.
} 
and purchases to enforce judicial decisions. The second case deals with the procurement of hepatitis $\mathrm{C}$ medicine Sofosbuvir and the price differentiation after a patent was granted and later suspended, which is evidence for possible anti-competitive excessive pricing and/or abuse of dominant position.

Finally, the text provides some theoretical conclusions on the relation between courts and IP. It firstly proves that the role of courts in implementing TRIPS flexibilities is in itself a factor that determines or at least influences the behavior of actors in the field. As such, courts are not arenas, but actors that influence competition and restructure markets. This pushes for the recognition that patent use and patent abuse, including practices in patent filings such as evergreening and sham litigation, are legal phenomena that can be at least partly regulated differently by law. In fact, by shedding light and putting all pieces of this interaction together, there is a need for a different interpretation of IP law. Theoretically, it means a law that is more thoughtful of socio-economic consequences and of existing contexts, which aims at addressing economic structures rather than reinforcing them.

The article concludes by proposing an interpretation of IP law which is integrated with competition law principles, both oriented towards, and based on, public interest provisions. Overall, we argue that this is a better framework than regarding IP and competition law as 'complementary' and to address issues of how courts may be misused by economic actors due to fragmentation of the two legal fields. Moreover, this interpretation is derived from international law, from the theoretical foundations of IP and competition laws, and from the historical development of substantive national provisions - and not a mere theoretical speculation. Furthermore, such endeavors are part of an emerging body of what some could even call "global law"; in this case, it means a nod for the transnational implications of national IP cases beyond its original realm.

\section{Assessing the Role of Courts in TRIPS Flexibilities As Forms of Structural Change}

In previous works, the authors have argued that the strong interplay between economic power and law are so pervasive that structural interventions are needed in order to prevent law from becoming a mere instrument of economic interests, and to instead promote broader societal goals. ${ }^{12}$ A "neo-structuralist" approach ${ }^{13}$ means that individual, moral(istic), and even institutional explanations are insufficient and even sometimes misleading. Therefore, efforts to ensure the full implementation of TRIPS flexibilities need to rely on a legal interpretation that is structural in the sense of taking into account the role of economic structures of pharmaceutical monopolies and ready to counter their negative consequences when needed. The approach

\footnotetext{
${ }^{12}$ Salomão Filho (2013a) and Salomão Filho and Ido (2019).

${ }^{13}$ Salomão Filho (2015).
} 
generally proposes that, willingly or not, legal interpretation will either be accepting of the status quo (adopting compensatory mechanisms at most) or transformative in a structural way. This analysis provides some inputs for a legal proposal for the role of courts to be less formalistic - in its intimate, self-referred and negative connotation-and more mindful about structural intervention through the application of public values. Whether courts wish to acknowledge this role or not, adjudicators will invariably perform it.

Specifically on the topic of TRIPS flexibilities, achieving broad access to medicines for all knowingly demands structural reforms in the current R\&D model for pharmaceuticals, a high-level policy commitment by governments to act boldly, and a major rethinking in the behavior of companies. ${ }^{14}$ None of this is primarily a task of any courts around the world; none is exclusively a legal enterprise. Indeed, judges and decision-makers should operate within the realm of existing laws and have, in the majority of circumstances, a limited role for structural change. This is all true. However, it should equally be stressed that structural change is a task that includes courts and includes legal thinking. Legal interpreters need to rely, even if partly, on philosophical foundations and legal theories for the interpretation of concrete cases. Judges and adjudicators reflect certain viewpoints and distinct ideologies even if they do not acknowledge so. ${ }^{15}$

Both considerations seem particularly relevant to IP and access to medicines, where notions of innovation, public interest and limits of monopolies are deeply intertwined and even part of ordinary legal arguments on IP. ${ }^{16}$ Considering how the implementation of IP norms around the world since the TRIPS Agreement has been the result of a push by developed countries and their industries, ${ }^{17}$ courts that adopt a formalist and limited approach will invariably reproduce the notion that IP needs to be expanded at all costs. This disregards that TRIPS flexibilities, including a focus on technological development and public health, are all primarily legal and legitimate tools. As such, if courts would strictly "follow the law", they should enforce the

\footnotetext{
${ }^{14}$ For a critical overview of the current R\&D model, see Velásquez (2020).

${ }^{15}$ For a compelling general critique, see Kennedy (1997); for an example of how courts may incorporate neoliberal values despite claims of impartiality, see Sanghera (2015), available at: https://www.opendemocracy.net/en/odr/unmasking-central-asias-neoliberal-judges/; for how a community of adjudicators and lawyers defines certain arguments in international arbitration and assumes a central role for a transnational legal order, see Dezalay and Garth (1996).

${ }^{16}$ Examples would include the interpretation of the common clause on exception of patentability due to "public order", dependent not only on an understanding of what "public order" means, but also how it is applicable in an analysis of a patent application. For an overview, see Bently (2011), pp. 315-347. Real cases show the need for courts to decide on multiple elements at once when faced with concrete cases, from patentability of living organisms to the limits posed by religious and morality laws to alleged obscene patent applications (see, for instance, Pankhuri and Shamnad (2018), available at: https://spicyip.com/2018/08/the-morality-of-sexual-pleasure-patent-officetraining.html).

${ }^{17}$ Sell (2003).
} 
validity of TRIPS flexibilities, and be particularly aware of the socio-consequences to the public interest of patents and other intellectual property rights. ${ }^{18}$ In other words, courts have the potential of de facto limiting the policy space of a country, and it is no surprise that so much effort is now given to the role of courts as part of the international economic architecture. ${ }^{19}$

In developing countries, these considerations are even more evident for two reasons: on one hand, the material conditions of access to medicines are generally worse ${ }^{20}$ on the other, the majority of such countries contain constitutional and legal provisions that advocate for implementation of socio-economic rights (such as health) and development goals, often in more directive and transformative ways than the counterparts in industrialized economies. ${ }^{21}$

Therefore, courts' stance on TRIPS flexibilities is of utmost importance, such as the position towards the validity of stringent patentability criteria for pharmaceuticals and the use of competition law to address anti-competitive practices in IP and health cases. Courts do not need to be "advocates" nor political actors to applying IP

\footnotetext{
${ }^{18}$ This can be traced back to the very foundation of intellectual property law scholarship, such as that of Italian Tulio Ascarelli, with profound repercussions to Brazilian commercial law, among others. For Ascarelli (1970), p. 276.

${ }^{19}$ Apart from intellectual property and TRIPS flexibilities, such considerations could be extended to multiple realms, such as international investment law (particularly investor-state dispute settlement-ISDS) and business and human rights litigation for environmental disasters, in which both pro-private biases and formalist views on jurisdictions and conflict of laws effectively lead to transnational economic deregulation. For notes on the impact of courts' rulings in international economic governance, see Muir-Watt et al. (2019) (for a compilation of cases that redefine the boundaries of public and private, and highlight the increasing interdependence between national and international jurisdictions); and for a more theoretical account, Muir-Watt (2016), pp. 347-428. ("despite the contemporary juridification of international politics, private international law has contributed very little to the global governance debate, remaining remarkably silent before the increasingly unequal distribution of wealth and authority in the world. [...] According to the genealogy of private international law depicted here, the discipline has developed, under the aegis of the liberal divides between law and politics and between the public and the private spheres, a form of epistemological tunnel-vision, actively providing immunity and impunity to abusers of private sovereignty.); see also Zumbansen (2012), pp. 899-925.

${ }^{20}$ See the final report of the United Nations Secretary-General High-Level Panel on Access to Medicines (2016) for some considerations. The language agreed as part of the Sustainable Development Goals (SDGs), especially SDG 3 on health, should also be stressed: "Target 3.b.Support the research and development of vaccines and medicines for the communicable and non-communicable diseases that primarily affect developing countries, provide access to affordable essential medicines and vaccines, in accordance with the Doha Declaration on the TRIPS Agreement and Public Health, which affirms the right of developing countries to use to the full the provisions in the Agreement on Trade-Related Aspects of Intellectual Property Rights regarding flexibilities to protect public health, and, in particular, provide access to medicines for all.”. There is broad consensus on the need of specific, and often bolder action, in the context of developing countries.

${ }^{21} \mathrm{See}$, for instance, the constitutional provisions that have been deemed, among other terms, "transformative" and "social", including those of Brazil (1988), South Africa, (1996), Colombia (1991), Bhutan (2008) and India (1950), just to name a few remarkable examples. See, for theoretical discussions: Uprimny (2011); Bonilla Maldonado (2013); Mendes (2013), 272p; Iyer (2019), pp. 359-385; Hailbronner (2017), pp. 527-565.
} 
law in a manner that is consistent with broader societal goals such as ensuring access to medicines. However, they sometimes refrain from doing so on such grounds. As we have noted before, the mere lack of decision is also a crucial feature in the lack of their implementation. ${ }^{22}$ In this context, advocates for judicial adjudication as a purely neutral and technical process do not address the negative impact this very stance has or might have on access to medicines.

\section{Access and Innovation in Legal Discourse: From Opposition to Coexistence}

There is one economic narrative that has profoundly influenced the debate on IP and access to medicines: the rhetoric whereby IP is an enabler of innovation, to the extent which it provides incentives for inventors, and therefore is also a prerequisite for access to future technologies. ${ }^{23}$ In short, no access without IP. Importantly, this has been often converted into a self-standing legal argument, either underpinned or explicitly referred to, in multiple cases, without further consideration of historical and empirical circumstances of the real markets they address.

The objective of this section is not to delve deeply into the broader debate on IP and innovation, and how IP affects access to the outcomes of future and existing

\footnotetext{
${ }^{22}$ The argument is also valid in the other direction: sometimes, measures taken by courts (such as investigations) have an indirect effect that is sufficient for social results. For instance, in the Hazel Tau case (2003), when the South African Competition Commission publicly announced that would sanction pharmaceutical company Glaxo-Smith-Klein (GSK) for the abuse of the exercise of its patent rights by charging excessive prices, a settlement was reached and no decision was taken. For an overview, see Knowledge Ecology International (KEI). CPTech's 2003 reports for the RSA Competition Commission, in Hazel Tau et al. v GSK, Boehringer, et al. Available at: https://www. keionline.org/competition/2003-hazel-tau-tac.

${ }^{23}$ For example, the director-general of the International Federation of Pharmaceutical Manufacturers \& Associations (IFPMA), Thomas Cueni, noted in a Financial times article on 17 May 2020 that "Patents, and IP more generally, are the main reason that there is such a strong innovation base to work from to find solutions" (Cueni, Thomas. Intellectual property is not a hindrance but a help to end Covid-19, Financial Times, available at: https://www.ft.com/content/e82dd07c-95c5-11ea899a-f62a20d54625). Another example of the utilization of this rhetoric is found in the official stance of the United States Trade Representative (USTR)'s Special 301 report of April 2020 "To promote affordable healthcare for American patients today and innovation to preserve access to the cutting-edge treatments and cures that they deserve tomorrow, USTR has been engaging with trading partners to ensure that U.S. owners of IP have a full and fair opportunity to use and profit from their IP, including by promoting transparent and fair pricing and reimbursement systems", available at: https://ustr.gov/sites/default/files/2020_Special_301_Report.pdf. Similarly, in a publication by the International Federation of Pharmaceutical Manufacturers \& Associations (IFPMA), it is noted that "A robust, time-limited system of patent protection is proven to facilitate development of, and access to, innovative pharmaceutical products and processes. In particular, a wellfunctioning patent protection system is a prerequisite for attracting finance for costly pharmaceutical research, given its high failure rates, by ensuring that successful innovation is rewarded". Gawel (2016), pp. 45-53.
} 
innovation, but to note how the conversion of this narrative into a legal argument is highly problematic. According to this view, less IP protection would necessarily lead to less innovation and therefore less access. This means that protecting IP would always be, according to this particular narrative, in the public interest. ${ }^{24}$ Accordingly, if IPRs are to be anyhow limited or restricted-even when they were wrongfully granted in the first place - this argument will consider that innovation will be hampered and, as a final result, access will be compromised. ${ }^{25}$

However, this assumption is remarkably questionable. For one, the role of IP in fostering innovation is far from clear. ${ }^{26}$ Some markets are innovative and creative despite the lack of exclusivity rights, ${ }^{27}$ and in many cases, IP is simply detrimental to innovation. A number of evidence-based studies propose that the barriers created

\footnotetext{
${ }^{24}$ In this sense, it performs the same functional role that theories on IP as natural rights once had. Treating IP as a natural right tends to maximize its protection. Conversely, treating IP as a temporary monopoly granted by the State requires a public interest justification based on the incentives provided by it. The "IP as channel of innovation" argument leads to the same maximization of IP as natural rights without needing to give away the notion that IP only exist to provide market incentives. It creates an overarching and somehow incontestable argument to consider that IP should always be expanded (in order to "achieve innovation"). This leads to very pragmatic consequences on the role of courts in IP law. When courts adopt fully this latter myth, the balancing of private and public interests in IP becomes a de facto imbalance gearing towards the private interest only. It becomes a tool for an adjudication that is incapable of properly taking into account public needs in the protection of IP. For a comprehensive critical analysis of patent law and history, which could include a reflection on the very adequacy of the "public and private balancing in IP", see Pottage and Sherman (2010).

${ }^{25}$ One such example is found among opposers of compulsory licensing, despite their recognition as a legal and legitimate tool under multiple international law instruments, including the WTO Doha Declaration on Public Health (2001). For instance, in a preliminary ruling on a class action in Brazil requesting the compulsory licensing of medicine Kaletra (lopinavir/ritonavir) due to high prices, the judge considered that "issuing a compulsory license would trigger retaliation by the developed world and possible shortages of the drug, while the very capacity of domestic industry to produce the medicine in Brazil was also called into question". See Costa et al. (2008). In a similar sense: "Patents benefit society in a number of ways, and although their specific role in each industry is unique, they are generally recognized for their ability to spur innovation. In the pharmaceutical industry, for example, patents are essential to motivating and directing future innovation, which generates new and better medicines for all. [...] The promise of immediate and improved access to brand name HIV/AIDS drugs is definitely alluring, but issuing or threatening a compulsory license has consequences. Compulsory licenses not only reduce foreign investment, they also impose costs related to litigation, safety, and efficacy.” Borowski (2009). http://ir.law.fsu.edu/lr/vol36/iss2/6.

${ }^{26}$ Boldrin and Levine have famously argued against patents: "The case against patents can be summarized briefly: there is no empirical evidence that they serve to increase innovation and productivity, unless productivity is identified with the number of patents awarded - which, as evidence shows, has no correlation with measured productivity". Boldrin and Levine (2013), pp. 3-22. Moreover, the importance given to the number of patents as a measure of innovation has been challenged not only as inaccurate, but also representative of a process of financial speculation of patents as credits and even as financial assets. For such critique, see Kang (2020).

${ }^{27}$ For an overview, see Darling and Perzanowski (2017). For a specific case, see Lemos and Castro (2012), on the tecnobrega music style in Northern Brazil as an example of an open business model which relies its success on the sharing of music without enforcement of copyrights.
} 
by IP serve not as catalysts, but hinderances, of innovation. ${ }^{28}$ Notions of "patent trolls" and "patent thickets", where strategic patenting filing leads to an overlap of multiple IP rights that unfairly block competition, have become a major issue for contemporary markets. ${ }^{29}$ As economist Joseph Stiglitz noted, following the US Supreme Court Myriad Genetics case (2013), which defined that isolated genes cannot be patented, "innovation has been accelerated, leading to better diagnostic tests [...] at much lower costs." ${ }^{30}$ Accordingly, it is possible to argue that markets without patents may be equally or even more innovative than those with IP protection and simultaneously also conducive to better access conditions.

Furthermore, for many accounts, IP has been historically an inefficient incentive at best. ${ }^{31}$ The development processes of the overwhelming majority of now industrialized countries were based on copying strategies, national industrialization and the creation of innovation ecosystems that include know-how and skilled professionals. In fact, IP has been deemed a limitation to development and innovation in most cases. ${ }^{32}$ The innovation landscapes of highly innovative countries in current

\footnotetext{
${ }^{28}$ See Heller (2010); Heller et al. (1998), pp. 698-701. For some, this means an IP system that does not deliver what it originally promises: "Intellectual Property rights are becoming increasingly badly configured in the developed world, leading to a stifling of innovation, distortions in the direction of innovation, and a reduction in the benefits which accrue from any innovation that occurs. Many of these failures arise because there is, especially under currently prevalent IPR regimes, no clear relationship between the social returns to innovation and the private returns. The proliferation of me-too drugs, the increase in patent hold-ups and similar excesses buttress the argument that the IPR system in the developed world is poorly configured." Baker et al. (2017), available at: http://ip-unit.org/wp-content/uploads/2017/07/IP-for-21st-Century-EN.pdf.

${ }^{29}$ See Matthews and Gurgula (2016). Queen Mary School of Law Legal Studies Research Paper No. 233/2016. Available at SSRN: https://ssrn.com/abstract=2779014.

${ }^{30}$ Stiglitz (2017), available at: https://www.theguardian.com/business/2017/oct/18/intellectualproperty-laws-demand-a-21st-century-solution.

31 "Both theory and the preponderance of historical evidence suggest that development, at least in its initial stages, is best promoted by a weaker intellectual property regime than reflected in TRIPS, or at the minimum a markedly different regime.” Baker et al. (2017), available at: http://ip-unit.org/ wp-content/uploads/2017/07/IP-for-21st-Century-EN.pdf.

${ }^{32}$ See, for instance, the landmark book Schiff (1971). Irregular or protection exclusively for nationals was also a feature in the United States, Germany and the United Kingdom. The studies on the socio-economic transformation of Japan, and then the Asian Tigers and more recently China, also prominently play a crucial role in a developmental State process that had little to do with the protection of foreign IP, relying instead on imitation and adaptation processes, at least in its earlier stages. For instance, Japan provided protection for national applicants but low protection for foreigners in the decades after WW2-a strategy later emulated by other late industrializing regions with high levels of innovation, such as South Korea and Taiwan. This is all relatively well-known and increasingly defended as means to assess even current practices by the very same players that actively put pressure in the international arena for developing countries to adopt higher standards of IP protection against what they have done in the past and also what they continue on doing. See, for instance, Chang (2002) and Amsden (2001).
} 
times are also not reliant on IP alone, ${ }^{33}$ even if the extent of its impact is debatable. In fact, even among its strong defenders, there is a general consensus that IP is not necessarily conducive to innovation at all times, ${ }^{34}$ and that in particular the effects of patents differ between industrialized and developing countries. ${ }^{35}$ An example of the detrimental consequences to access without accruing any benefits of innovation is the early implementation of the TRIPS Agreement in Brazil in 1996, which can be contrasted with the relative positive experience of India. ${ }^{36}$

\footnotetext{
${ }^{33}$ Highly innovative countries do not adopt a laissez-faire approach and contain enormous funding for basic research, different research grants and direct investments alike. Examples include massive investments by DARPA and BARPA US agencies. For an assessment of the role of the State in innovation and the economy more broadly, see Mazzucato (2013).

${ }^{34}$ See, for instance, Fink and Raffo (2019).

${ }^{35}$ IP may possibly serve as an incentivizing mechanism in industrialized countries with a robust pharmaceutical industry already in place, with proper financial mechanisms, large public grants in early stages of research and research institutions and universities with large capacity and expertise. It will however not produce such an effect in countries with different profiles, and the historical global evidence in developing countries seems very clear in that regard. In summary, the already contested effects of IP towards innovation are even less compelling in the Global South, precisely where issues of access have been the most pressing and negative. The fact that HIV treatments were effectively rendered available in African countries around 10 years after they were available, leading to the unnecessary death of literally millions of lives, is no overstatement. For some broad considerations, see Cimoli et al. (2014). For a defense of the idea that prices should necessarily be lower in developing countries, and dissociated from any notion of compensation for investments, see Salomão Filho (2007), pp. 160-161.

${ }^{36}$ Brazil and India are among the very few countries in the Global South which have developed solid national generic industries (public and private). In both countries, the creation and consolidation of national pharmaceutical industries took place in the absence of IP incentives in the mid-twentieth century. In fact, similarly to the majority of the Global South, laws had been amended as to remove pharmaceutical patents from its national laws, a clear industrial and developmental policy measure. While the lack of IP was definitely not the only element that enabled the rise of pharmaceutical industries, they were seen as a clear barrier to the development of emerging industries. In Brazil, public laboratories such as Farmanguinhos and Butantã Institute play a crucial role in ensuring manufacturing of vaccines and medicines at affordable prices, as well as worldknown R\&D and public health research. India was able to consolidate the largest generic pharmaceutical market of the world and is still lauded as a prime example of success, deemed the "pharmacy of the [developing] world". Nonetheless, despite relatively comparable benchmarks, the implementation of TRIPS led Brazil and India to remarkably different paths. While Brazil opted to enact an Industrial Property Law in 1996, not fully enjoying the crucial TRIPS flexibility to only recognize pharmaceutical patents in 2001, India used it fully until the latest possible deadline in its case (2005). A major promise of the proponents of the Industrial Property Law of 1996 in Brazil was the need to "modernize" the national system and "promote investments and innovation". Yet, the granting of pharmaceutical patents in Brazil is overwhelmingly composed of foreign applicants, and combined with the lack of other policy incentives for the national industry, the result was a major negative impact in terms of its industrial capacity. It also has no signs of innovation output growth at all in the pharmaceutical sector. In fact, the new patent system created disincentives for generic companies due to their legal risks: as almost all of those benefitting from patents were foreign applicants, the investment in R\&D in Brazil for pharmaceuticals actually declined and many generic firms are said to have become particularly conservative in their business practices, delaying competition even further. Even if the majority of the Indian companies are not lead innovators in the
} 
Finally, there are also particular issues with any direct association between IP and innovation in legal thinking. The TRIPS Agreement and many national laws note that IP requires a constant balancing between public and private, the public value pertaining to access to medicines being one of paramount importance. ${ }^{37}$ Patents are granted taking into account the public interest related to the disclosure of the invention and competition; they are an exceptional, limited and temporary legal bundle of exclusivity rights granted by the State solely in, and to the extent which it favors, the public interest. ${ }^{38}$ As a consequence, the impediments created by IP as barriers to access should always be taken into account in the interpretation of concrete cases more prominently.

Indeed, the pharmaceutical sector is a particular and very sensitive case. On one hand, R\&D investments are higher than most other industries, and risks are larger, with few successful products out of a much larger pipeline of candidates. On the other, in this field, there is much more public investment in R\&D (in many cases the main investment is public not private) because its products are or at least should be essential goods, as they directly relate to health, sometimes as a life or death dilemma. Perhaps curiously, these arguments have been utilized to sustain opposite views: both the need for less or no patents (prioritizing access) and for more patents (prioritizing innovation). In light of the overview above, the problem with the debate framed in such a way is that it reinforces a questionable direct relation between IP, innovation and access.

Many have empirically exposed, for instance, that the enactment of compulsory licensing has not had detrimental effects to foreign investment and has not undermined innovation overall, ${ }^{39}$ and successful cases have drastically reduced prices and therefore enhanced access to medicines. Additionally, the global community increasingly acknowledges that a model based only on patent protection is

pharmaceutical field, they have proven remarkably successful in ensuring access to medicines worldwide. Its economic importance to the country is also huge. See, for comparisons and analyses of the political economy of such countries, Shadlen (2017) and Vanni (2020).

${ }^{37}$ Articles 7 and 8, TRIPS Agreement: "Article 7 Objectives. The protection and enforcement of intellectual property rights should contribute to the promotion of technological innovation and to the transfer and dissemination of technology, to the mutual advantage of producers and users of technological knowledge and in a manner conducive to social and economic welfare, and to a balance of rights and obligations Article 8. Principles 1. Members may, in formulating or amending their laws and regulations, adopt measures necessary to protect public health and nutrition, and to promote the public interest in sectors of vital importance to their socio-economic and technological development, provided that such measures are consistent with the provisions of this Agreement. 2. Appropriate measures, provided that they are consistent with the provisions of this Agreement, may be needed to prevent the abuse of intellectual property rights by right holders or the resort to practices which unreasonably restrain trade or adversely affect the international transfer of technology". For the effective implications of this tension in various countries and situations, see Dreyfuss and Rodríguez-Gavarito (2014).

${ }^{38}$ In light of these considerations, it makes sense to conceive IP in terms of bundles of rights instead of an absolute and unitary right.

${ }^{39}$ For example, Inthira et al. (2011), p. 7:28. 
not the best incentive for innovation in the pharmaceutical sector, and alternatives exist. ${ }^{40}$ For example, Amy Kapczynski compellingly describes the open science network of the Global Influenza Surveillance and Response System (GISRS), where "a global influenza virus-sharing network that has for decades produced critically important information goods, at significant expense, and in a loose-knit group-all without recourse to $I P ",{ }^{41}$ which both responds better to societal health needs and does not treat innovation and access as a trade-off.

The global initiatives seeking the development and subsequent "equitable and affordable" access to Covid-19 vaccines and treatment, treating them as "global public goods" and as a "people's vaccine", ${ }^{42}$ with support by key actors such as the European Union and China, have highlighted the needs for collaborative efforts. Unprecedented funding and multiple actions have been taken, including the creation of the voluntary WHO Covid-19 Technology Access Pool on the basis of a proposal by Costa Rica, ${ }^{43}$ public international pledges for more resources, ${ }^{44}$ as well as private pledges for making IP-protected technologies related to Covid-19 free of charge. ${ }^{45}$ It highlights a possible new approach to global pharmaceutical R\&D, not based on competition, but rather on intense sharing of information, which may produce faster and much more accessible outcomes in terms of health products.

\footnotetext{
${ }^{40}$ It is not a surprise that calls for a renewed R\&D model for pharmaceuticals are a constant demand in international discussions. See, for instance, Velásquez and Seuba (2011) (calling for a mandatory international agreement on pharmaceutical R\&D at the World Health Organizaation); Stiglitz and Jayadev (2010), pp. 217-226 ("promoting prizes over patents; directing innovation toward socially beneficial outputs by adopting some form of value-based pricing; publicly funding clinical trials to reduce conflicts of interest while reducing costs; and actively managing frontier technologies to maximize positive social spillovers"). Proposals on prizes are among the most common alternative, at least in academia. See, for instance, the proposed Health Impact Fund-HIF (https:// healthimpactfund.org/). Nowadays, alternative R\&D models do exist for neglected diseases, such as the successful non-profit organization Drugs for Neglected Diseases Initiative (DNDi), which has already achieved approved medicines for neglected diseases under substantially lower R\&D costs if compared to large transnational pharmaceutical firms for most diseases (https://www.dndi.org/). CEPI-Coalition for Epidemic Preparedness Innovation (https://cepi.net/), founded in 2017, may also serve as an alternative model for financing future vaccines, including for Covid-19. It is currently funded by industrialized countries and charities such as Bill and Melinda Gates Foundation and the Wellcome Trust. Unlike DNDi, the exact access conditions in case of a successful candidate are however yet unclear and subject to debates.

${ }^{41}$ Kapczynski (2017) Available at: https://scholarship.law.cornell.edu/clr/vol102/iss6/3.

${ }^{42}$ For an analysis of the debate and how it has been partly incorporated (albeit with major limitations) into the 73rd World Health Assembly Resolution "Response to Covid-19" in 2020, see Syam et al. (2020).

${ }^{43}$ See WHO COVID-19 Technology Access Pool (C-TAP): https://www.who.int/emergencies/ diseases/novel-coronavirus-2019/global-research-on-novel-coronavirus-2019-ncov/covid-19-tech nology-access-pool.

${ }^{44}$ See European Commission Press Release. "Coronavirus Global Response: €7.4 billion raised for universal access to vaccines". 4 May 2020, available at: https://ec.europa.eu/commission/ presscorner/detail/en/ip_20_797.

${ }^{45}$ See Open Covid Pledge: https://opencovidpledge.org/.
} 
Again, in this sense, a more efficient approach that may achieve more innovation and broader access. ${ }^{46}$

Finally, a caveat to the association between IP and innovation refers to the real costs of R\&D, which are deeply non-transparent, and where, as noted before, the role of public funding is pivotal. ${ }^{47}$ It challenges once again the assumption of a necessary trade-off, rendering explicit instead the possibility of achieving a coexistence between access and innovation. More transparency on the pharmaceutical sector could enable courts to rely not on the general, abstract notion that IP is conducive to innovation, and instead make an empirical assessment of, for instance, how much public funding the medical product received or not, how the final net pricing has been fixed, and the exact socio-economic repercussions of a patent or other IP to the market. This would mean a better balance between private and public interest in IP and access to medicines.

In summary, this section aimed at presenting two important points for adjudicators dealing with IP and access to medicines to consider:

1. arguments that entangle the protection of IP with innovation and access are an improper interpretation legal technique, which disregards the socio-economic and developmental implications of IP as much as it tends to limit the role of the public interest in IP. ${ }^{48}$

2. access and innovation are not a necessary trade-off: under many (and perhaps most) circumstances, collaborative and deeply competitive markets are more inventive and also provide better access conditions.

As a conclusion, adjudication in IP and access to medicines calls for an evidencebased and thoughtful analysis of what is really at stake in a particular case. From a legal point of view, the broader pharmaceutical sector regulation can be interpreted

\footnotetext{
${ }^{46}$ For a proposal, see Mazzucato and Torreele (2020), available at: https://www.project-syndicate. org/commentary/universal-free-covid19-vaccine-by-mariana-mazzucato-and-els-torreele-2020-04.

${ }^{47}$ While pharmaceutical companies may insist some of this information is trade secret (therefore legally protected), much of this data is actually not. A landmark Resolution at the 72nd World Health Assembly (WHA/72.8) agreed on the need for more transparency in the pharmaceutical industry, including net prices, but falling short of including specific commitments to the transparency of R\&D costs. Moreover, much attention has been given to the role of public funding in pharmaceutical innovation, particularly in earlier stages, which is neither recognized nor reflected in safeguards in terms of affordability and accessibility for the very public that financed it in the first place. For an overview of existing literature, see Vieira and Moon (2019), available at: https://www. knowledgeportalia.org/public-funding-of-r-d; Vieira and Moon (2020), available at https://www. knowledgeportalia.org/cost-of-r-d.

${ }^{48}$ Rather than conclusive remarks on the relation between intellectual property and innovation-or more precisely, the multiple relations between IP, access and innovation-, the crucial point to be made is that courts have no clear evidence to decide based only on the premise that IP is a necessary element to achieve innovation. However, this is exactly how many courts are inclined to argue; or, at least, by exacerbating the role of IP in innovation without a proper balance with public interests related to access, courts will also be inclined to maximize IP protection in the detriment of all other stakeholders, patients included. Therefore, as a conclusion, it is necessary to disentangle IP and innovation as separate categories, with a direct impact to legal interpretation.
} 
in a way that secures both access and innovation, and not as a trade-off as a departing point. The following section attempts to exemplify how a legal rationale in that sense could take place, and what may happen when this is not taken into account. By doing so, it will also be possible to reflect on what role do courts have in TRIPS flexibilities' implementation.

\section{Trastuzumab High Price Litigation in Brazil}

Trastuzumab (sold under brand name Herceptin) is a groundbreaking medicine for the treatment of breast cancer, listed as essential medicines by the World Health Organization (WHO). ${ }^{49}$ Breast cancer is a disease that kills thousands of persons, especially women, yearly around the world. In Brazil alone, 53.680 cases were reported in 2013, and more than 56.000 in 2014. Trastuzumab was developed by Genentech, a pharmaceutical company based in San Francisco, United States, which later licensed to Swiss pharmaceutical ${ }^{50}$ company F. Hoffmann-La Roche (henceforth Roche) for US\$40 million upfront, later sharing royalties with Genentech. ${ }^{51}$ In practice, Roche is the owner of patents related to the drug and manages them. According to a Forbes article on 28 August 2019, Trastuzumab "is the leader in the breast cancer drugs space with annual sales of around $\$ 7$ billion", accounting for about $15 \%$ of the overall profits of Roche yearly. ${ }^{52}$

Given how essential the medicine is ${ }^{53}$ and its very high prices overall, various concerns about access to Trastuzumab have been highlighted in multiple jurisdictions around the world by civil society organizations. The production cost of the medicine is reported to be around US\$240 for a 1-year supply. ${ }^{54}$ Nonetheless, as reported by Médécins sans Frontières in 2017, Trastuzumab's annual prices were set at around US\$ 38365 for the private sector and US\$ 15735 for the public sector in

\footnotetext{
${ }^{49}$ World Health Organization (2019).

${ }^{50}$ Grupo Direito e Pobreza (Law and Poverty Group) (2014).

${ }^{51} \mathrm{Hu}$ et al. (2020).

${ }^{52}$ Forbes (2019), available at: https://www.forbes.com/sites/greatspeculations/2019/08/28/canroches-blockbuster-drug-herceptins-sales-grow/\#62da696a42e5.

${ }^{53}$ In fact, from a competition perspective, all cancer drugs are essential in terms of the demand side, given the severity of the disease. As it is literally a matter of death or life, the equilibrium point between offer and demand is drastically influenced by a hugely inelastic demand. This means that structurally such drugs tend to be highly priced under purely market conditions, and therefore particular attention to potential competitive abuses is necessary. In other words, this means a careful assessment of pricing and how offer takes place.

${ }^{54}$ See Hoen (2019) Strong call for transparency on medicine prices, cost of R\&D at WHO Fair Pricing Forum. Medicines Law and Policy https://medicineslawandpolicy.org/2019/04/strong-callfor-transparency-on-medicine-prices-cost-of-rd-at-who-fair-pricing-forum/.
} 
South Africa, where patents will only expire in $2033 .{ }^{55}$ Brazil, as we will expose in more details, prices were also extremely high: unaffordable for patients and unsustainable for the public budget. It is further relevant to note that the basic patent of Trastuzumab has expired in many other countries, including the USA. In both USA and Europe, there are already biosimilar versions available in the markets, which contributes to reducing prices. In Brazil, due to the patent extension term for cases of backlog of patent applications (provided for by Article 40, sole paragraph, of the Industrial Property Law (Law 9279/1996) and currently pending constitutionality ruling at the Federal Supreme Court ${ }^{56}$ ), the patent will not expire until 16 June 2028. ${ }^{57}$

However, even the lack of patent is no guarantee of reduced prices per se. In India, where patent oppositions had been filed, Roche withdrew patent applications on Trastuzumab. Still, the company has relied on litigation against biosimilar producers through India's drug regulatory body, which effectively enables Roche to be the sole provider of the medicine in the country as well. ${ }^{58}$ This has been taken to the Indian Competition Commission as a possible abusive conduct for stalling the approval of generic drugs. 59

These facts are important evidence to highlight that high prices of Trastuzumab are not only caused by its uniqueness, as there are already biosimilar medicines available in international markets, and that the balancing between profits and health seem to be radically unaligned. The similarity of high prices around the world further denotes a tendency of monopoly pricing and abuse of patent.

The medicine was registered by the Brazilian regulatory agency ANVISA as early as 1999 and was incorporated as a treatment provided for by the public health

\footnotetext{
${ }^{55}$ See MSF Global day of action against Roche's inhumanity \#RocheGreedKills. Press Release, 6 February 2017 https://msfaccess.org/global-day-action-against-roches-inhumanityrochegreedkills.

${ }^{56}$ Direct Unconstitutionality Claim (ADIN 5529). The judgment is expected to scrutinize whether the mentioned Article 40, Sole Paragraph of the Industrial Property Law is constitutional or not. It provides an extension of patent terms due to patent backlog by establishing that a patent has a minimum term of 10 years of protection. Since the general term is 20 years, any patent application procedure that lasts longer than 10 years leads to an extension in the overall term of protection. However, the competition effects of such extensions are dramatic. The strongest interpretation of Brazilian constitutional legal system and the majority of commentators seems to note that such legal provision is unconstitutional-similar to provisions on pipeline patents, also not yet judged by the Brazilian STF. In this sense, it becomes clear how it is important to acknowledge how the lack of action by the court-in such cases by refraining from deciding - is a central piece in the understanding of their role in the implementation of patents in Brazil, and how they negatively affect the implementation of TRIPS flexibilities.

${ }^{57}$ According to the analysis by the Law and Poverty Research Group, University of São Paulo, the first known patent that refers to Trastuzumab was filed on 3 November 2008; its unionist priority dates back to 16 June 2008. See Grupo Direito e Pobreza (Law and Poverty Group) (2014), p. 6.

${ }^{58}$ See MSF Access Campaign Global day of action against Roche's inhumanity \#RocheGreedKills (2017), https://msfaccess.org/global-day-action-against-roches-inhumanity-rochegreedkills.

${ }^{59}$ Competition Commission of India. Case No. 68 of 2016-Roche-Mylan Biocon CCI Order 68 of 2016.
} 
system SUS in 2012. Cancer prevention, detection, treatment and control are all covered by the public health system. Nonetheless, diminishing prices was a condition for effective access to take place after its incorporation as a registered medicine paid by the SUS. During that occasion, and discounted taxes, prices of Trastuzumab were $62 \%$ higher than international price average and $115 \%$ of the lowest reported international price (surprisingly or not, in the United States). ${ }^{60}$

Public procurement bids were conducted by the Ministry of Health in order to generate economies of scale, later distributing to State Health Secretaries under Brazilian federalist system. After direct negotiations with Roche, prices were reduced from $\mathrm{R} \$ 7.860,26$ per dose, charged in 2007, to $\mathrm{R} \$ 3.446,89$ in 2012 (without taxes, prices in Brazilian Real). However, State Health Secretaries have also been obliged through individual health claims, to provide Trastuzumab. This is a consequence of Brazil's widespread "judicialization of health", which enables individuals to go to courts demanding specific medicines and treatments, also obliging public entities to provide them regardless of costs in the majority of cases. ${ }^{61}$ In practice, this means that there were two main routes for access to Trastuzumab: via the general

${ }^{60}$ Grupo Direito e Pobreza (Law and Poverty Group) (2014).
${ }^{61}$ This is a direct translation from the Portuguese "judicialização da saúde", or "judicialización" in Spanish. Brazil's legal system is characterized by an ample recognition of the right to health, including universal health system, the SUS, which are both constitutionally protected (Articles 6 and 196, Federal Constitution of Brazil, 1988). This has been interpreted as a direct constitutional mandate which allows thousands of individual claims for medicines and treatments to reach courts, which have been in general granted in almost all cases, even experimental treatments and no matter the costs. The process has been also identified in other Latin American countries, particularly Colombia, Argentina and Costa Rica. In common, public budgets are overwhelmed by such claims, which are in certain cases a very large proportion of overall budgets. In 2019 and 2020, two landmark rulings by the Supreme Federal Court (STF), the country's highest judicial instance, drastically reduced such claims as to avoid an overburden for health systems, in light of the recognition that individual claims affected the social realization of health rights. For a critical overview, see Kapczynski (2019), available at: http://humanityjournal.org/issue10-1/the-right-tomedicines-in-an-age-of-neoliberalism/. She notes that "The budgetary impact of the right to medicines cases has unsurprisingly been significant. According to government figures, from 2010-2016, the federal government spent 4.4 billion reais (\$1.4 billion) to comply with judicial decisions, with most of this going to provide medicines. 49 This sum has risen sharply over time, along with the number of cases.50 In 2016 alone, the federal government spent 1.2 billion reais (\$400 million) to satisfy judicial mandates.51 The bulk of suits for access to medicines arises at the state level, where data are harder to come by. But analysis has found that states and municipalities may be spending anywhere from 3 to 10 per cent of their health budgets to satisfy right to health cases, and as much as 22 per cent of their medicines budgets to fulfill judgments mandating access to medicines.". She further notes the impact of patents as one of the main causes for such high costs: "Why are the medicines involved, or more accurately, some of the medicines involved, so profoundly expensive? It is common ground that the "exponential growth in costs" in Brazil "can be explained by a high concentration of cases demanding expensive patented drugs." 81 Almost 80 per cent of the total sum spent by the federal government to satisfy judgments for medicines in 2011 was spent on just 20 medicines, for fewer than 0.05 per cent of litigants". For a concern about the possibly deceptive and anti-distributive character of such claims, see Wang (2015), p. 617; for a defender of its counter-hegemonic potential as a grassroots instrument for the poor, despite its shortcomings, see Biehl et al. (2016). 
Table 1 Unity prices of Trastuzumab before July 2012 (in Brazilian Real—BRL)

\begin{tabular}{|c|c|c|c|c|c|c|}
\hline \multirow[b]{2}{*}{ Trastuzumab } & \multicolumn{3}{|l|}{ Brazil } & \multirow{2}{*}{\begin{tabular}{|l}
$\begin{array}{l}\text { Lowest } \\
\text { price }\end{array}$ \\
\\
USA
\end{tabular}} & \multirow[b]{2}{*}{$\begin{array}{l}\text { International } \\
\text { Average }\end{array}$} & \multirow[b]{2}{*}{$\begin{array}{l}\text { International } \\
\text { Median }\end{array}$} \\
\hline & $\begin{array}{l}\text { CMED }^{\mathrm{a}} \\
\mathrm{PF}^{\mathrm{b}} \\
\text { (with } \\
\text { taxes) }\end{array}$ & $\begin{array}{l}\text { CMED } \\
\text { PF } \\
\text { (without } \\
\text { taxes) }\end{array}$ & $\begin{array}{l}\text { CMED PF } \\
\text { (without } \\
\text { taxes and } \\
\text { CAP }^{\text {c }} \text { ) }\end{array}$ & & & \\
\hline $440 \mathrm{mg}$ vial & $\begin{array}{l}\mathrm{R} \$ \\
9.417,81\end{array}$ & $\begin{array}{l}\mathrm{R} \$ \\
7.640,60\end{array}$ & $\begin{array}{l}\mathrm{R} \$ \\
5.969,60\end{array}$ & $\begin{array}{l}\mathrm{R} \$ \\
3.555,67\end{array}$ & $\mathrm{R} \$ 4.728,98$ & $\mathrm{R} \$ 4.832,21$ \\
\hline
\end{tabular}

"CMED is the acronym for "Câmara de Regulação do Mercado de Medicamentos" (Chamber of Regulation of Medicine Market), the Brazilian federal regulatory agency responsible for monitoring prices and establishing caps according to the prices of selected markets around the world, including the United States

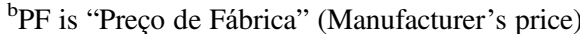

"CAP is "Coeficiente de Aplicação de Preço" (Price Application Coefficient, in Portuguese) is a mandatory minimum discount applied for medicine purchases by public administration entities, such as the Ministry of Health

Recommendation Report by CONITEC/SUS - Trastuzumab for Treatment of Initiatial Stage Breast Cancer-July 2012, p. 16

universal public healthcare system and via individual court litigation. If this, on one hand, may pressurize public entities to provide better healthcare services and avoid individual claims, on the other hand, this dual system creates strong inequalities in terms of who may access medicines and when (often with "shortcuts"). An oftendisregarded issue regarding this topic is how this system may also present an opportunity for abusive pricing conducts and patent abuses. In the specific case of Trastuzumab, Roche provided the medicine under a price agreed by the public bid, but refused to sell Trastuzumab for the same price in individual healthcare litigation cases, charging instead $\mathrm{R} \$ 7.192,00$-more than double the negotiated with the Ministry of Health. Further evidence shows that similar higher pricing occurred for all purchases not related to the centralized procurement, i.e., all individual litigations (Table 1). ${ }^{62}$

In light of this data, the Law and Poverty Research Group of the University of São Paulo (USP) produced a comprehensive report on the prices charged by Roche on Trastuzumab, reporting the figures above. It then filed in June 2014 a "representation" (i.e. a form of denunciation mechanism) for the Federal Public Ministry of Brazil, the authority mandated with the protection of collective rights in the country and general overseer of the public interest. ${ }^{63}$

The research group noted that the price differentiation between markets is a case of abuse of dominant position, a doctrine of competition law but applicable more broadly to this case also, and further noting a case of excessive pricing given the

\footnotetext{
${ }^{62}$ Grupo Direito e Pobreza (Law and Poverty Group) (2014).

${ }^{63}$ Grupo Direito e Pobreza (Law and Poverty Group) (2014).
} 
existence of market power by Roche. The company in this case was apt to discriminate between consumers without justification, leading to an overprice. ${ }^{64}$ According to the legal document, they are in violation of the constitutional economic order and of a conduct of arbitrary profits (Articles 170 and 173, $\S \$ 4$ and 5 of Brazilian Federal Constitution). In this sense, although some arguments are usually found only in competition/antitrust law, the case dealt with civil torts.

Finally, the average price charged in Brazil above the international average was utilized as grounds for another evidence of abusive conduct, according to Brazilian law. This takes into account precisely the monopolistic power of Roche in an international context, with discretion to charge higher prices in jurisdictions where, at least in theory, prices should be lower. With these elements, the research group's representation requested the launch of an investigation by the Federal Public Ministry, demanding damages in the benefit of the public, the compulsory licensing of Trastuzumab, the immediate parallel import of biosimilars and for all conditions for local manufacturing to be available.

Indeed, the Federal Public Ministry welcomed the document and later filed a collective claim ("Inquérito Civil n. 1.16.000.000699/2015-87", which proposed the civil public action) against Roche in 2016, replicating the arguments above and further considering that, while within the boundaries of the maximum regulated prices by CMED, they were still abusive due to the stark differentiation. ${ }^{65}$ Notably, prices were much up to three times higher than those in the United States, and more than double of the international average. The decision to pursue a judicial litigation was rooted, among others, in the dissatisfaction with the laboratory's formal response. The Federal Public Ministry requested all purchases to be equated with the centralized public procurement price, and requested a compulsory licensing to be issued and the immediate authorization for parallel imports.

In August 2018, however, the Federal Court of the Federal District (Brasilia) responsible for the case agreed with Roche that there was no demonstration of price abuse nor illegal conduct, since Roche had brought justifications. ${ }^{66}$ As a conclusion, the whole situation described above remained unchanged. While there was an appeal

\footnotetext{
${ }^{64}$ For a more thorough analysis of market power, and the use of the Lerner Index doctrine borrowed from competition law, see Salomão Filho (2013b), p. 152.

${ }^{65}$ The existence of a regulation on medicine prices does not remove it from the scope of potential abusive practices regarding prices, an argument that was inaccurately explored by Roche. In reality, the price regulation (not a direct price fixing) cannot be used to shield liability from abusive pricing. It means that the Judiciary should acknowledge that there is potential abusive conduct in charging excessive prices of medicines, even if they are regulated. Furthermore, CEMED's methodology is criticized for establishing excessively high price caps, which would also prove the point.

${ }^{66}$ Among the arguments of the defendant, Roche argued that logistics costs are much higher when destined to a specific litigation, unlike the larger public procurements. Indeed, the relatively more complex molecule (being a biological drug) and specific needs for storages do pose difficulties regarding its manufacturing and logistics. The weakness of the argument is demonstrated by the fact that Roche sells other drugs in different places in Brazil with no such regional differencesshowing therefore that the difference in price is in effect due to market power and illegal price discrimination.
} 
filed against such decision, taking the case to the Appeals' Federal Court and pending final decision, some members within the Federal Public Ministry (claimant) opposed the continuation of this litigation.

Meanwhile, Roche also joined a Partnership for Productive Development (PPD) with the Ministry of Health, securing transfer of technology for national laboratories Tecpar and Axis, while guaranteeing a market (following this agreement, $40 \%$ of all purchases by SUS would come from Roche). In theory, PPDs would lower prices, even if higher than direct competition. However, once again, prices went up, which led to another proceeding in August 2019, this time by the Union Audits Court ("Tribunal de Contas da União"), a quasi-judicial administrative court responsible for auditing public expenses, for abusive pricing. ${ }^{67}$ This case is still pending at the conclusion of this paper.

From this description, a few preliminary comments can be made. In this particular case, the existence of patent protection over Trastuzumab was the defining feature that permitted Roche Brazil to charge monopolistic prices, putting the public health sector in an extremely unequal position (having one sole provider of a product with an extremely inelastic demand). If generics to Trastuzumab were available, individual litigations could also purchase from the alternative providers, and the bargaining power of Roche towards the Brazilian public sector would be much more limited. Moreover, it is possible to conceptualize this behavior in relation to public purchases and court rulings as an abuse of patent rights under Brazilian competition law: although often disregarded, the way market players may benefit economically from legal uncertainty, multiple case filings and lack of competitors should be under the scrutiny of competition and IP law alike, not only as background facts, but as evidences. All in all, this is equally an important call for the inclusion of responsibilities of companies in litigations of public interest such as those related to access to medicines.

What is the direct result of this federal judicial ruling? The maintenance of the status quo and an implicit legitimization of Roche's pricing practices. Also, while the new investigation at the Union Audits Court is unrelated to the previous one, it allows other reflections, including what is the relation between them and what are the possible legal impacts of one investigation in the other. The fact that this case has been framed as a "non-patent" issue or which has perceived the market monopoly power conferred by a patent as ancillary at best is the result of the limited understanding pointed out in the Introduction: failing to acknowledge the role of courts in individual litigations to enhancing the power stemming from a patent in this particular web of details, the ultimate result does not properly apply the public interest requirements of Brazilian IP and competition laws.

Finally, even though a preliminary analysis could possibly focus on the role of the individuals involved in the litigation, this description highlights in fact that the

\footnotetext{
${ }^{67}$ Junqueira (2019). Available at https://www1.folha.uol.com.br/cotidiano/2019/08/investigacaodo-tcu-aponta-sobrepreco-em-remedio-para-cancer-e-leva-a-desabastecimento.shtml.
} 
functioning of the IP system is extremely reliant on the role of courts. ${ }^{68}$ As stated before, this is less about individual biographies of adjudicators/attorneys/businesspeople and more about a judicial system based on silos and typically reluctant to commit to applying law in a more comprehensive manner, even in light of such socio-economic circumstances. This has been moreover a case where a hesitant and absent role of the Judiciary to address IP and access to medicines issues has directly impacted the possibility of implementing access to medicines policies, even if at first glance this seems to not be a case on patents or competition. Importantly, the argument of how price differentiation by Roche was only being possible due to the complex web of various litigations had indeed been brought to courts, but the decisions overall preferred to interpret the facts in a much more limited way.

\section{The Sofosbuvir Case in Brazil}

Sofosbuvir - sold under the brand name Sovaldi by pharmaceutical multinational company Gilead Sciences-is a key medicine for the treatment of Hepatitis C, for decades an incurable disease. It has been deemed a long-waited game changer for the treatment of the disease. The utilization of direct-acting antivirals (DAAs) such as Sofosbuvir, in combination with other drugs, ${ }^{69}$ is able to provide a cure in a very high percentage of cases (over 95\%), and also contains a drastic reduction of collateral effects in comparison with the most utilized treatment for decades until then, based on inter-venous use of Interferon. Since its launch, Sofosbuvir has been a major commercial success for Gilead around the world, with estimations of billions of dollars in profits, largely superseding its overall investments in R\&D by any possible account. ${ }^{70}$

The major global concern on Sofosbuvir has been the fact that it is extremely costly in developed countries and in the majority of middle-income countries. It has been reported that the 12-week treatment has cost up to US\$84.000 in the United States. In countries with generic offer, such as those coming from Egyptian generic company Pharco Pharmaceuticals, the same treatment can be provided for as low as US\$300. ${ }^{71}$ Importantly, Egypt did not grant the patent on Sofosbuvir, and Gilead

\footnotetext{
${ }^{68}$ See Sect. 2 for some inputs on this topic.

${ }^{69}$ Combinations include sofosbuvir with ledipasvir, velpatasvir, simeprevir and/or dataclasvir. Dataclasvir is patented by Bristol Meyer Squibb (BMS), while ledipasvir and velpatasvir have also been patented by Gilead. Other companies similarly have DAAs placed in markets and more are in the pipeline of new drugs.

${ }^{70}$ According to an estimation by Hep C Coalition, a patient's of hepatitis C advocacy group, in the period 2013-2018 the drug generated a profit of around US\$25.8 billion. Nonetheless, access to Sofosbuvir globally was still extremely reduced due to pricing, patents and registration delays. See: https://hepcoalition.org/news/press-releases/article/hepatitis-c-cure-sofosbuvir-turns-5-years-oldthe-vast-majority-of-people-still?lang=en\#nb1.

${ }^{71}$ See: https://www.dndi.org/2018/media-centre/press-releases/new-affordable-hepatitis-c-combi nation-treatment-shows-97-cure-rate/.
} 
has offered a much lower price of US\$900 per treatment, since Pharco Pharmaceuticals was also able to produce it. ${ }^{72}$ The real beneficiaries were consumers and the public health sector of Egypt, which could have access to a full treatment at substantially lower prices than the majority of countries in the world. Importantly, the fact that prices are so dramatically different around the world is another evidence that pricing is a process that is disentangled from innovation processes. ${ }^{73}$

Gilead established a large international scheme of voluntary licenses for certain Indian generic companies to produce and export Sofosbuvir at very low prices to least developed countries (LDCs). ${ }^{74}$ However, middle-income countries (including Brazil) were not part of the scheme at all. Such agreements also prevent competition with non-licensee generic producers, and also impede exports to territories not covered by the licenses. Thus the majority of world population in need remained excluded from this beneficial scheme. ${ }^{75}$ For those countries, the medicine remained an extremely pricy drug, and likely even more in countries with weaker health systems. This led Sofosbuvir to be at the central stage of global efforts for reduction of prices, campaigns for affordable and equitable access, and different attempts by governments to reduce prices, including the issuance of a compulsory license in Malaysia. ${ }^{76}$ Patent oppositions have been filed in multiple countries, including Argentina, Brazil, Morocco, Egypt, Ukraine, Malaysia, India, China, Russia, the United States, Vietnam and in the European Patent Office (EPO), ${ }^{77}$ some with successful outcomes to have a patent claim rejected or limited.

With millions of hepatitis C patients, Brazil incorporated DAAs as part of the universal public health system and opted in 2014 to negotiate prices of Sofosbuvir

\footnotetext{
${ }^{72}$ Correa and Velásquez (2018).

${ }^{73}$ While net prices do relate to numerous variables, including logistic costs, costs of APIs (active pharmaceutical ingredient), taxation, volume of purchases, reimbursement schemes, and others, these stark price differences between countries were mostly related to patents. The fact that Gilead Sciences as a transnational corporation group (despite separate legal entities) had the monopolistic power to discretionarily charge higher prices across jurisdictions shows this even more clearly. Medicine prices covered by patents are ultimately influenced by patents (therefore, by a monopoly), and not related to innovation. This is yet another caveat to the logic described in the previous section, to which a patent and its exercise, including the economic benefits arising from it, would be at least partly justifiable due to the innovation provided. What economic evidence shows, however, is that if prices and patents were really related to innovation, prices should be at least somewhat similar in the world, which does not happen at all. As such, this is a clear case of what antitrust law considers to be a monopoly pricing.

${ }^{74}$ Hill et al. (2016), pp. 28-31.

${ }^{75}$ Gilead. Chronic Hepatitis C Treatment Expansion - Generic Manufacturing for Developing Countries. Available at: https://www.gilead.com/-/media/files/pdfs/other/hcv-generic-agreementfast-facts-11-15-17.pdf.

${ }^{76}$ Press Statement Minister of Health 20th September 2017 - Implementation of the Rights of Government for Sofosbuvir Tablet to Increase Access for Hepatitis C Treatment in Malaysia. Available at: https://kpkesihatan.com/2017/09/20/press-statement-minister-of-health-20th-septem ber-2017-implementation-of-the-rights-of-government-for-sofosbuvir-tablet-to-increase-accessfor-hepatitis-c-treatment-in-malaysia/.

${ }^{77}$ See https://www.patentoppositions.org/en/drugs/sofosbuvir.
} 
with Gilead directly. While a positive initiative that prevented prices from being even higher, Sofosbuvir sold for the public health system through public procurement mechanisms was estimated to be up to 52 times more expensive than generic versions available in other countries, according to GTPI, a Brazilian civil society organization. ${ }^{78}$ From the outset until the present moment, while lower than the maximum charged in the United States, prices in Brazil were substantially higher than countries with generic availability such as Egypt and Malaysia (following its compulsory license).

Multiple patent applications had been filed by Gilead at INPI, the Brazilian IP office. In February 2017, Fiocruz files a pre-grant opposition to the main patent application (PI0809654-6). MSF Brazil, GTPI/REBRIP, and other organizations would follow. From the very beginning, the patent applications were controversial: in March 2017, ANVISA denied the prior approval ("anuência prévia") to the patent. ${ }^{79}$ In March, the National Council of Health ("Conselho Nacional de Saúde") issued a technical-political recommendation against the patent and called for attention to public health needs. However, in May 2017, a preliminary injunction questioned ANVISA's decision and it was therefore, according to the Brazilian legal system, legally bound to grant its prior approval-with the possibility of this decision to be upheld or overruled in later stages. In practice, the court ruled that the prior approval should be granted.

In its pre-grant opposition on the same patent application, GTPI/REBRIP, argued that it did not meet patentability criteria, but also further noted that the patent application in question referred to an essential drug, and therefore its granting would lead to violation of the right to health of Brazilian population. While this explicit public interest argument was not utilized, the INPI released on 19 April 2018 a preliminary technical examination report against the patent. While not legally binding, it signaled that the patent would not be granted. On 5 June 2018, ANVISA gave the regulatory approval for the generic drug to be produced locally by a Farmanguinhos-Fiocruz and Blanver (a generic company) partnership. It was largely expected that the patent would not be granted at this point. In June 2018, daclatasvir, dimeprevir and sofosbuvir were incorporated in the Brazilian SUS; they were expected to be distributed freely and universally by December 2018 .

On 18 September 2018, in an unexpected decision, INPI granted the patent on one of the 126 substances filed, having denied 125 others and reversing its own

\footnotetext{
${ }^{78}$ Grupo de Trabalho da Propriedade Intelectual (GTPI). Brazil is excluded from license authorizing production of generic medicine for hepatitis C. Available at: http://deolhonaspatentes.org/ media/file/GTPI_statement_Gilead_license_sofosbuvir.pdf.

${ }^{79}$ The prior approval was an innovation of the Brazilian Patent system whereby the regulatory agency ANVISA conducts an analysis of the patent application for pharmaceuticals, granting or not its "prior approval" before the INPI analysis. The interaction between the two agencies and the mandate of ANVISA have been hotly debated. In early times, ANVISA would conduct a full patentability criteria analysis and its decision was binding; this was later replaced to be an analysis of public health implications of the technology patent application, but no veto power per se is recognized as of now.
} 
preliminary technical examination. The main compound was not patented, but still, the decision was met with outcry and major discontent by civil society and patient groups. Although in principle generics could be produced if they did not infringe this limited patent, any generics reaching markets, in this case, would be subject to costly and limiting litigation. This risk is substantially higher in Brazil for generic companies given the fact that damages for patent infringement are necessarily set at the highest possible amount, which hinders competition. ${ }^{80}$ Subsequently, the generic medicine was legally and effectively blocked from entering the markets and Gilead enjoyed a legal monopoly due to its new patent.

Shortly thereafter, on 20 September 2018, Marina Silva, a former environment Minister and presidential candidate filed a federal lawsuit against the INPI decision in order to annul the patent, based on arguments of public health and on the precarity of the patent application, citing, among others, precedents in other countries. ${ }^{81}$ The federal judge in Brasilia accepted the arguments and issued a preliminary injunction suspending the effects of the patent. ${ }^{82}$ During this period, it can be said that there was a competition period, whereby patents were not a barrier to competition and the generic version was able to be commercialized and be part of public bids of Sofosbuvir-based treatments. The price reached an all-time low of $\mathrm{R} \$ 64,84$ (also see graphic below for the comparison).

In November 2018, combination medicines containing Sofosbuvir were procured at an emergency procedure by the Ministry of Health. Gilead filed a claim to impede its distribution due to patent infringement. In this context, a decision in favor of Gilead is taken but later overruled. ${ }^{83}$ In December 2018, the preliminary ruling in Brasilia was overruled and the patent on Sofosbuvir is once again valid, leaving Gilead to wait for its patent letter to start enforcing it. It is noteworthy to mention that the decision by the Federal Court in Brasilia-1st Region was taken on procedural grounds and was therefore not based on substantive patentability requirements. ${ }^{84}$

Following the previous decision, a decision by a Rio de Janeiro Federal Court in December 2018 suspends, under request of Gilead, PDP between Blanver and

\footnotetext{
${ }^{80}$ See Articles 44, 1,208 and 209 of the Brazilian Industrial Property Law. For an assessment of how this maximalist set of norms impacts competition by greatly increasing the risks for generic companies, see Gabriela et al. (2018), Fiocruz \& Escola Nacional de Saúde Pública Sergio Arouca, pp. 122-139.

${ }^{81}$ Silva, Marina. Petição Inicial de Ação Popular (Statement of Claims of Popular Lawsuit).

${ }^{82}$ Ação Popular n. 1019631-97.2018.4.01.3400. Judgement on 23 September 2018. ("acknowledge that the INPI, by not facing explicitly the arguments that the patent application here questioned was not in tune with the social, technological and economic interest of the country (from the point of view of the Program to Combat Hepatitis C, maintained by the SUS), it disrespected its constitutional obligation to preventively oversee national sovereignty and public interest, in the exact extent of art. 5O, XXIX, Federal Constitution, and arts. 2 and 18, I, from Law n. 9.279/96"; free translation).

${ }^{83}$ See https://oglobo.globo.com/sociedade/em-nova-batalha-de-patentes-remedio-para-tratamentoda-hepatite-pode-ser-barateado-23584500.

${ }^{84} \mathrm{See}$ https://www.jota.info/paywall?redirect_to=//www.jota.info/tributos-e-empresas/saude/juizrevoga-liminar-que-quebrava-patente-de-remedio-contra-hepatite-c-21122018.
} 
Fiocruz/Farmanguinhos for the production of generic Sofosbuvir until final decision on patent is taken. ${ }^{85}$ This effectively suspended the generic in Brazil. Also in December 2018, Gilead commits to reducing prices in public procurement. ${ }^{86} \mathrm{How}$ ever, still much higher than the generic version. Gilead received its patent in mid-January 2019. In February 2019, Gilead won major public procurements of Sofosbuvir in Brazil.

This intricate description of events means temporally the occurrence of three main phases:

1. a de facto monopoly, when there was only a patent application and Gilead was the sole provider of Sofosbuvir; ${ }^{87}$

2. a short competitive market period where the recently granted patent was suspended due to a preliminary injunction based on public interest provisions, and the generic version was able to enter the market;

3. a legal monopoly phase after the patent was reinstated, with only Gilead again in the market. ${ }^{88}$

It should also be highlighted the number of legal actions taken by all parties, but in particular Gilead, which utilized various different legal tools, including infringement claims of its then suspended patent and attempts to nullify public procurement bids that would have competition. Furthermore, while indeed the patent granted to Sofosbuvir is not on its basic compound and some generics could theoretically still be produced, in practice, some of the public bids are only available to Gilead. In short, the current situation at the time of writing is of full legal and de facto monopoly for the patent holder (Table 2).

The most decisive feature of this case, however, deals with the prices charged after the patent was reinstated, as they were substantially higher than those from the competition phase, but also from the original de facto monopoly situation. According to another report by the Law and Poverty Research Group, there was a spike of up to $1421.55 \%$ between the competition market period in mid (prices as low as $\mathrm{R} \$ 64,84$ on average) and the later patented phase ( $\mathrm{R} \$ 986,57$ on average),

\footnotetext{
${ }^{85}$ Case n. 050277092320184025101, Federal Court of 2nd Region, Rio de Janeiro.

${ }^{86}$ See SBAC (2019) http://www.sbac.org.br/blog/2018/11/28/dona-de-patente-que-barra-genericocontra-hepatite-c-promete-desconto-a-governo/.

${ }^{87}$ As noted in footnote 80 , in Brazil, patent applications provide a very strong market power in comparison to other countries. This is partly related to the legal provision that establishes damages for patent infringement (including patent applications) at the maximum possible level in favor of the patent holder (Articles 208 and 209, Industrial Property Law) - with retroactive effects (Article $44, \S 1$ of the same Law), which greatly discourages competitors from entering markets. Brazilian legal doctrine in patent law has also similarly sustained a view that patent applications are deserving of an almost, if not equivalent, level of protection as granted patents. Due to this specificity, the possibility for Gilead to charge a monopolistic price even before the granting of a patent is much clearer than it would be in many other jurisdictions.

${ }^{88}$ See Grupo Direito e Pobreza (2019).
} 
Table 2 (Extract from Law and Poverty Research Group report) Effect of Introduction of Generic Sofosbuvir (Blanver/Farmanguinhos) in National Market

Effect of Introduction of Generic Sofosbuvir (Blanver/Farmanguinhos) in Brazilian Market

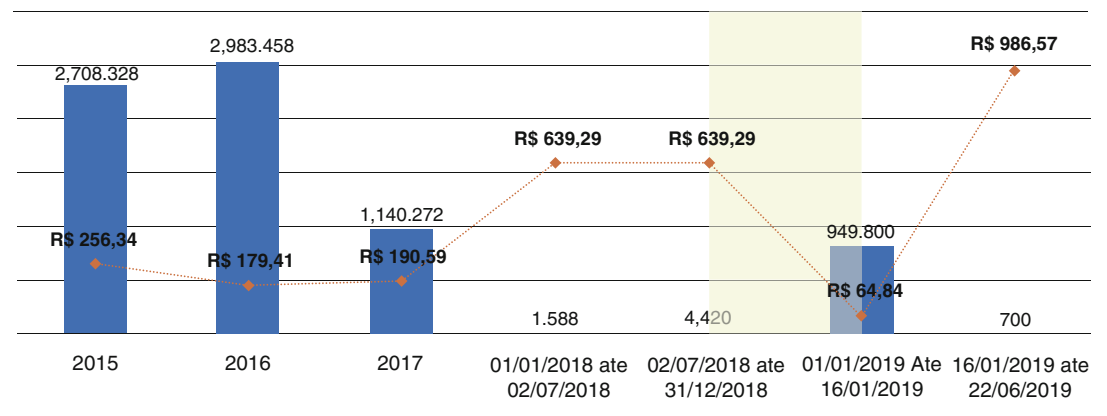

- Sofosbuvir units sold by Gilead to the Brazilian State during the period

-... Average unitary price of Sofosbuvir sold by Gilead during the period

representing an overwhelming extra budget toll for the public sector. ${ }^{89}$ Furthermore, between the legal monopoly phase in 2019 (patented market) and the de facto monopoly from 2015-2018, there is also a major difference in pricing. For instance, in 2016, where a large number of Sofosbuvir units were purchased, the average unit price was $\mathrm{R} \$ 179,41$, compared to $\mathrm{R} \$ 986,57$ charged in 2019 during the new patent monopoly.

This complex intertwinement in the case calls for antitrust scrutiny. In light of the situation, a group of nine different Brazilian civil society organizations, representing both patient, consumer and human rights groups, as well as the Public Defenders of Brazil, filed a joint formal notification to the competition authority (CADE ${ }^{90}$ ) in order to request the launch of an investigation for abusive anti-competitive practices (both excessive pricing as abuse of dominant position and abuse of patents) and asking for adequate remedies to be taken, including issuing a compulsory licensing

\footnotetext{
${ }^{89}$ Grupo Direito e Pobreza (2019). Importantly, Even though they refer to different public entities, as noted in the case of Trastuzumab, from a competition perspective, this is the same relevant market (public national health market, as essentially all procurements discussed here are made by the public sector, even if sometimes via different entities - e.g. Ministry of Health and Health Departments of States of Municipalities). The research also aggregated not only Sofosbuvir (Sovaldi), but also a combination of medicines: Harvoni (Sofosbuvir + ledipasvir) and Epclusa (sofosbuvir + velpatasvir).

${ }^{90}$ CADE-Conselho Administrativo de Defesa Econômica (Brazilian Administrative Council for Economic Defence).
} 
for Sofosbuvir on the grounds of an anti-competitive conduct (Article 31k of TRIPS and Art. 38, IV, "a" of Brazilian Competition Law, Law 12.529/2011).

A preliminary administrative investigation was indeed launched by CADE, but the case remains open. It might reach the Administrative Tribunal Council, which decides upon antitrust cases in Brazil. At first impression, there seems to be more space for a competition authority to address the case than judicial courts. ${ }^{91}$ However, the relatively more flexible administrative procedure under competition law and the stronger pressures on administrative bodies by government and interested private companies (patent holders) make the results uncertain. This is especially the case at a time in which pharmaceutical industries effectively threaten countries with possible delays in the supply of Covid-19 related medicines (Gilead's voluntary licensing of Remdesivir, which excludes middle-income countries-including Brazil-is an example ${ }^{92}$ ). Despite the yet inconclusive outcome of this preliminary investigation by CADE, the subsequent steps are largely dependent on how the institution decides to perform or not such role.

\section{Theoretical Conclusions on the Role of Courts in IP Based on the Concrete Cases}

The two cases reveal a number of issues on the interconnectedness between IP protection and the role of courts. A different kind of interpretation on the role of the Judiciary and other courts (including competition authorities' adjudication bodies and regulatory bodies, when applicable) with regards to patent protection may thus be enabled. This section aims at presenting some theoretical conclusions drawn partly from the cases discussed and examples presented.

a) Courts can reshape markets (and are also influenced by them). As such, patents and patent use or abuse can be seen mainly as a legal phenomenon and their scope depends on the enforcement given to the monopoly in different jurisdictions.

\footnotetext{
${ }^{91}$ For instance, given their broad mandate, their relative reduced number (if compared to judicial courts), and the transnational characteristics of most cases (which impact and deal with conducts/ structures in multiple jurisdictions), most competition authorities are equipped for joint international investigations, work through the sharing of information and to adopt a comparative approach in terms of arguments and remedies deployed. In this sense, they are more accustomed to use case law from other jurisdictions as direct and indirect basis for their own judgements. From an international economic law perspective, it is also true that there is also more policy space for competition authorities to pursue objectives than IP courts. Also, CADE has been one of the first authorities to particularly address an abusive conduct case pertaining to IP, which is the sham litigation case by pharmaceutical company Eli Lily (Administrative Proceeding N. 08012.011508/ 2007-91, from June 2015).

${ }^{92}$ Bermudez and Prabhala (2020). Gilead: o Brasil excluído no enfrentamento da pandemia. Available at: http://www.cee.fiocruz.br/?q=node/1176.
} 
Firstly, courts affect competition. Instead of purely arenas where legal arguments meet in search of a ruling that clarifies the law, they are rather active actors that end up determining the behavior of the parties involved in an IP dispute, even when adjudicators refuse to recognize this role. In other words, judicial rulings and courts are a factor that influences the economic behavior of patent holders, competitors and governments.

As a consequence, they may in an intended or unintended manner expand the patent monopoly's effective scope. For instance, if companies are aware of the extreme success rates of individual health litigation cases, such as it was the case of Trastuzumab in Brazilian courts, and that there is no scrutiny for the prices charged to the public sector in order to enforce judicial orders, this means that the patent monopoly is enhanced exorbitantly. It becomes an implicit authorization to charge any price, even if likely anti-competitive. Similarly, if companies know that their litigation practices and their price discrimination (between different entities in a same jurisdiction and/or across different countries) are to be considered lawful from a competition law perspective, such as what has been argued in the ongoing Sofosbuvir case before the competition authority (CADE), they also see their patent monopoly reinforced, allowing them to pretty much shield themselves from antitrust suits. The monopoly legally granted by a patent is not supposed to be so overarching and comprehensive. However, it may become so due to courts. The conclusion is that access to drugs is directly restrained.

In general, it is not possible to disregard the impact of courts; the absence of the Judiciary decision is also often the main feature to expand patent monopolies. The absence of rulings from the Brazilian Constitutional Court (STF) on patent matters since the enactment of the 1988 Constitution and the 1996 Industrial Property Law until a May 2021 decision which ruled automatic patent term extensions unconstitutional is a present and dangerous example of this absenteeism. Therefore, in short, courts can reshape markets (and are also influenced by them). As such, patents and patent use or abuse can be seen mainly as a legal phenomenon and their scope depends on the enforcement given to patent rights and its flexibilities in different jurisdictions.

b) "IP as crucial to innovation" wrongly becomes a legal argument, which hampers access

Secondly, rhetorical and economic narratives have direct legal consequences when turned into arguments deployed or accepted by courts. By applying as a given fact that maximal IP protection will lead to more innovation (therefore, according to this view, IP protection per se is in the public interest), courts impede an evidence-based assessment of concrete cases, preferring to rely on a pre-set definition. Most laws themselves do not define the specific trade-off related to patents, access and innovation, and invariably will require robust interpretation by courts in practical terms.

This means that there will be no real balancing between, for instance, the effects for competition or the impacts on prices and consequential increase in medicine prices, and the protection of a certain patent claim. Furthermore, an analysis of even "technical" aspects, such as patentability criteria, will tend to be informed and biased 
by a tendency towards the granting of a patent-similarly to the notion adopted by some IP offices that patent applicants are "clients", and not public offices working for the public interest.

The economic narrative that equals IP with more innovation tends to overly expand the scope of protection of IP from a temporary monopoly granted by the State (quasi-public right, for some) to a naturalized and almost absolute right. ${ }^{93}$ This, in a sense, is an effect of IP protection on the role of courts. This narrative has been implicitly seen in the two cases analyzed, especially through the arguments provided for by the law firms representing the pharmaceutical companies in Brazil. This is the main conventional stream of argumentation in pharmaceutical patent litigation and legislative debates around the world. ${ }^{94}$

c) Anti-monopoly and IP law share public principles. As such, principles of competition/anti-monopoly law should be directly applicable to patents (neither as exemption nor complement)

Thirdly, apart from an IP interpretation that is more sensitive to the socioeconomic implications of IPRs, there is a case to be made about the applicability of principles of anti-monopoly laws to patents. ${ }^{95}$ This should not be seen as an

\footnotetext{
${ }^{93}$ Oftentimes, the defense of TRIPS flexibilities mirrors the way the IP system is usually conceived: a tension between public and private interest, the public being the interest of society at large to benefit from more creations and inventions and access to them, and the private being the incentive/ recognition of the inventor/author to benefit, particularly economically, from it. The access to medicines debate, in that sense, is normally portrayed as a defense of more public interest to the relative detriment of the private interest of the IP holder. When put under those terms, the IP debate is defined as a permanent imbalance and a constant pursue of the balance between public and private. However, this should not necessarily be the case. The disaggregated framing of the question allows for different considerations. An essential point often not referred to in the IP scholarship is the impact of TRIPS flexibilities to the protection of IP. The flexibilities are neither an annulment nor an attempt to impede the exercise of legitimate IPRs. When patents proliferate and are granted under lax patentability criteria, it is well-established that this leads to the granting of numerous patents to non-inventions (i.e. patent applications that do not fit the novelty or non-obviousness, inventive step and industrial application requirements). Conceptually speaking, they should not be granted in the first place. This means that, from the outset, patents are not synonyms of inventions. However, if the patents granted to non-inventions are never subject to legal scrutiny-for instance, through post-grant oppositions or through judicial rulings that invalidate patents-they will be legally enforced.

${ }^{94}$ Another good example of how this comes about is in the anxieties surrounding the likelihood of international investment arbitration panels based on the measures taken by States with regards to Covid-19 IP-protected technologies, which may cause hugely detrimental effects to certain countries, show how deeply engrained the "IP as innovation" approach is. Similarly, as noted by James Love, "companies will be able to claim that anything that reduces the price reduces incentives to invest in more rapid development, and litigate that issue." See, Karlin-Smith (2020) https://www. politico.com/news/2020/03/05/coronavirus-drug-industry-prices-122412.

${ }^{95}$ See, for example, FTC v. Actavis US Supreme Court Case. In this case of a pay-for-delay agreement, the court acknowledged that competition law should be applied to patents. This is different from the previous US interpretation: before that, decision courts largely considered that a behavior that falls within the subject matter of the patent would be lawful, even if it had a negative
} 
exception or as a complement to the legal discipline of patents and other IPRs, but as an integral part of the meaning of IP: there is no IP without competition, even if it may sound paradoxical at first.

In practice, in relation to the Trastuzumab civil federal case in Brazil, this would lead to the recognition that the stark price differentiation between the price of public procurement and the price charged resulting from a judicial ruling against the State is so high that it should have been considered illegal. To do so, an application of principles of competition law, in particular a discipline of abuse of dominant position, would have been in our view sufficient to prove the case. The doctrine of competition law abuse of dominant position should definitely be applicable to this case, even if it was being ruled by an instance outside of the Brazilian competition law system. This would be arguably also the case in other jurisdictions. Conversely, for the Sofosbuvir competition case, the differences in the historical series of prices, and between the de facto monopoly, the legal monopoly (patent protection) and the competition situations (with generic drugs available in the market), highlight another anti-competitive practice based on both excessive pricing (price demonstrated through price discrimination) and abuse of patent power. ${ }^{96}$ As noted before, this case is still pending as of the conclusion of this paper.

While at first the difference in courts (federal judicial court and competition authority) would seem to lead to completely different legal reasonings and rationale of distinct bodies of law, in reality the similarity of cases denotes that the disciplines of IP and competition law-and also in tune with public interest provisions and fundamental rights - are or should be in fact in a path of merger. An IP court cannot dismiss competition law as much as a competition body should not ignore IP provisions; although they may have different organizing structures, and are usually seen as targeting different goals, they have increasingly similar objectives and intertwinements. Integrated principles and integrated disciplines does not mean conflating all norms, arguing that IP and competition law are the same (they are not), but it does mean passing from essentially private law spheres to a way of interpreting law that should be based on public principles, particularly in light of the demand that it should not reproduce socio-economic structures as natural entities, but instead seek to regulate them for their economic power, as we have argued before

effect on the market and could be considered anti-competitive. This highlights that even in a country so adamantly protective of patent rights, such as the United States, the possibility of applying patent law to competition law exists.

${ }^{96}$ There seems to be a proven argument in favor of an abuse of patent as an illicit anti-competitive conduct. This is a clear recognition under Brazilian law, but it is also a hypothesis clearly delineated by the TRIPS Agreement and therefore part of the national law of almost every jurisdiction around the world. Furthermore, even though the majority of pharmaceutical IP-related cases in antitrust bodies deals with "excessive pricing", such doctrine is neither the only nor the sine qua non legal argument to elicit the anti-competitive conduct. In other words, the illegality is not (only) in a price deemed excessive, but in the utilization of a legal monopoly position (the patent) in an abusive manner. Therefore the need to identify the two conducts. 
in different occasions. ${ }^{97}$ Both are informed by and conceptualized under public interest law more than bearers of private interests. This also means that the cases described above would have required a different kind of interpretation that adequately addresses competition impacts of IP protection both directly and indirectlyincluding the role of courts as such. As many have argued in terms of the evolution of both disciplines (IP and competition law), the trend towards a broader consideration of interests, consequences and stakeholders denotes a process of "publicization" of private law, rather than the opposite. ${ }^{98}$

d) There is an emerging global (case) law of TRIPS flexibilities based on screening and transparency. The role of courts is not dissociated from, but rather based on, an interaction between academia, NGOs and other actors.

Finally, a few notes should be made on how an emerging body of decisions taken by courts around the world has become a crucial feature for TRIPS flexibilities much beyond their own initial scope. Courts are increasingly required to navigate distinct "fields of law" and take into account other jurisdictions-both for the impact of their decisions and as sources of legal arguments. ${ }^{99}$ There is also a "screening" process between courts. ${ }^{100}$ Some national decisions have direct transnational repercussions, such as a ruling on the legality of parallel exports, which will impact countries which import or export medicines to that jurisdiction. An antitrust decision may deem illegal a conduct based on abusive exercise of IPRs, and may impose restrictions and sanctions that affect the outcomes of patent litigations in judicial courts.

\footnotetext{
${ }^{97}$ See Sect. 2.

${ }^{98}$ Salomão Filho (2015).

${ }^{99}$ While IP law seems to be tightly related to national jurisdictions and international treaties only, the increasing prominence of international licensing agreements in IP, the introduction of IP in investment arbitration panels and the interplay between different actors discussed in this paper as "pharmaceutical patent activism" highlight that courts need to navigate this much more complex landscape, both public and private, both national and transnational at the same time. This is at least partly applicable to this analysis. It also deals with other phenomena. For instance, in the field of constitutional law and international human rights law, some have referred to this as "courts' dialogue", whereby interpretation of certain rights and case law of regional human rights bodies such as the European Court of Human Rights and the American Court of Human Rights may influence each other, as well as national constitutional courts. Even if the expression may not be always accurate to describe constitutional practices, it does signal the possibility of crossreferencing based on sharing of experiences and case law. This does not compromise the sovereignty or the independence of courts, as evidently all such arguments and data needs to be assessed according to national laws and real cases. Instead, it provides more transparency and avenues for a better coordination between different societal actors, which may have the positive effect of increasing accountability.

${ }^{100}$ Positive screening is an expression most commonly found in the investment world of stock exchanges, whereby investors positively value companies with commitments such as environmentally-sound operations and human rights protection, among others. Here, the notion of "screening" is borrowed broadly from corporate governance in a critical way, where reputational costs and examples set by peers in a given market are an increasingly important form of informal governance.
} 
But in other cases, there are indirect consequences, which cannot be underestimated either. Landmark rulings such as the USA Supreme Court Myriad Genetics Case $^{101}$ and the Indian Supreme Court Novartis Case ${ }^{102}$ have been immensely discussed, read in law classrooms and utilized by courts around the world that in theory would not be bound anyhow by such decisions. Others have this emerging potential, such as the Kenyan High Court decision that, based on the right to health, struck down a law with a concept of "counterfeit" which ended up including safe and high-quality generic drugs. ${ }^{103}$ In this sense, they are a real source of law for other courts.

Similarly, pharmaceutical patent applications also have a transnational dimension. Pharmaceutical companies file patents around the world, sometimes translating the content of application claims without proper adaption to national laws. ${ }^{104} \mathrm{Civil}$ society groups and generic competitors counter applications of key medicines through patent oppositions in one jurisdiction, such as India, which then become the basis for subsequent oppositions in other countries. This can be deemed a form of "patent activism". ${ }^{105}$ The cases of Trastuzumab and Sofosbuvir, as previously noted in their respective descriptions, have both been subject to scrutiny and advocacy by patients' groups, and the dialogue between different actors and jurisdictions is a key feature for understanding the conducts and strategies deployed in Brazil.

${ }^{101}$ United States Supreme Court (2013), Assoc. for Molecular Pathology v. Myriad Genetics, Inc., 569 U.S. 576 (2013) (on patentability of an isolated gene).

${ }^{102}$ On constitutionality of Section 3(d) of the Indian Patent Act which establishes a robust inventive step requirement. For instance, Siva Tambisetty notes that "The decision in Novartis v UOI heralds a post-TRIPS coming of age for many jurisdictions like India, including Thailand, Brazil, Malaysia and Indonesia. There is an urgent need to build up legitimate legal standards, tests and principles around domestic patent legislation that do not replicate the predicament around patentability standards that several jurisdictions face". See Tambisetty, Siva. Novartis v. Union of India and the Person Skilled in the Art: A Missed Opportunity. LSE Law, Society and Economy Working Papers 2/2014. For Ahmed Abdel-Latif, the case was the first time a decision by a developing country court was so intensely scrutinized, and could bear consequences to other countries, see Abdel-Latif (2013), available at https://www.ip-watch.org/2013/04/15/the-novartis-decision-a-taleof-developing-countries-ip-and-the-role-of-the-judiciary/. Similarly, see Bennett (2014), p. 535 and its possible impacts.

${ }^{103}$ For a comment, see Kapczynski (2019).

${ }^{104}$ As patents are territorial, patent applications also need to be filed in multiple jurisdictions. Multiple streamlined and/or joint systems do exist, such as the WIPO-administered Patent Cooperation Treaty (PCT) system and regional patent systems such as the ones enabled by the European Patent Office and the OAPI-Organisation Africaine de la Propriété Intellectuelle.

${ }^{105}$ See, for instance, the work of Médécins sans Frontières-Access Campaign, ITPC - International Treatment Patients Coalition, Third World Network (Malaysia), Lawyer's Collective (India), GTPI-Grupo de Trabalho da Propriedade Intelectual (Brazil, for only a few examples of organizations working specifically on this field. Furthermore, a database such as that of the Medicine Patent Pool's Medspal, the compilation of TRIPS flexibilities by the Medicines Law \& Policy, or the compilation of compulsory licensing experiences such as that organized by the South Centre, are good examples that may be utilized by any courts around the world. For a comparison between India, Brazil and Nigeria (with a relative lack of "patent activism" in the latter), see Vanni (2020). 
Theoretically, these and other cases may be understood as part of global and transnational law, ${ }^{106}$ which may help to elucidate how specific courts are part of global economic governance, even as national decisions. As such, adjudicators are key actors in the consolidation of a global law of TRIPS flexibilities based on the sharing of positive experiences, transnational advocacy, international solidarity and in the benefit of developing countries. ${ }^{107}$ It should include not only finalized cases, but also legal proceedings initiated but not prosecuted, injunctions granted or not, negotiations and settlements, and activists campaigns. Furthermore, developing countries have an ever-growing importance in IP jurisprudence. ${ }^{108}$ The current Covid-19 pandemic and its multifaceted international reaction has a clear potential to accelerate and foster this process.

\section{Concluding Remarks}

This article sought to repurpose the relation between courts and the implementation of intellectual property. It argues for a shift from limited and uni-dimensional, i.e. "courts apply IP law neutrally", to broad and multi-dimensional, through which courts define the contours of IP law and are also mutually influenced by IP arguments, theories and stakeholders, all and each with specific socio-economic impacts. Access to medicines is a field where these considerations become more evident.

It proposed two main arguments. Firstly, that courts have an enormous impact on the implementation of TRIPS flexibilities. While they are and should not be the only variable in place, any efforts for advancing or curbing the flexibilities involves courts. In particular, tribunals shape markets, even when-and maybe particularly when-adjudicators decide to refrain from broader consideration of circumstances

\footnotetext{
${ }^{106}$ Again, as examples, refer to Muir-Watt, Horatia, 2013; Zumbansen, Peer, 2011. Sometimes, influences also come from non-state actors, such as arbitration panels, non-governmental entities such as ISO, ICANN and FIFA, and transnational private contracts. In private international law, notions of global law, transnational law and private ordering have been used to characterize a legal political economy - both from a descriptive and a normative point of view - that is not exclusively based on national and international law, but multiple normative setters.

${ }^{107}$ The theoretical framework of a decentralized and collective construction of a global/transnational law in IP means two things: on the normative side, that no single entity, no single individual and no single country should define the effective norms and policies of the whole world; on a descriptive point of view, that all players have an important role, and that this interplay between academia, civil society organizations, international organizations and judicial/administrative authorities is essential to construct a robust account of TRIPS flexibilities through example and mutual screening.

${ }^{108}$ Abbott, Drahos and Correa have argued that the world patent order was to be changed by the innovation and development of IP in developing countries, with a particular nod to the role of China, Brazil and India. This hypothesis can be now taken further to include the specific case law of these and other jurisdictions alike. Abbott et al. (2012).
} 
and socio-economic impact of their own decisions. For this reason, the role of courts itself (e.g. a ruling or a lack thereof) has competition impacts and should be taken into account in legal interpretation.

Secondly, that a specific narrative which associates IP protection with fostering innovation is misleading, as it establishes an incorrect trade-off between access to health products and innovation. Since it is widely deployed by courts without further consideration, this narrative turned into legal argument is particularly problematic for over-expanding the effective protection of IP without a balance with the public interest. Thus, it should not be accepted as a juridical category or narrative.

The description of the cases of Trastuzumab and Sofosbuvir in Brazil serve as examples of how these different pieces come together, even if sometimes indirectly and not explicitly. Many other rulings can and should be described under those lenses. This article may present a framework for further analyses that include, rather than ignore, the specific role of courts and their respective arguments on TRIPS flexibilities.

A general conclusion is that this set of elements justifies a legal interpretation that is mindful of structures such as patents, including their effects on societies and the need for them to be reformed, rather than exclusively based on an allegedly formalist interpretation of laws. Such laws, as described above, already enable the restructuring of patent interpretation according to TRIPS flexibilities. This could be deemed a "neo-structuralist" approach to patent law. ${ }^{109}$ These cases also lead to the recognition that IP and competition laws should be both interpreted jointly according to integrated public interest principles. ${ }^{110}$

Finally, the article posited that the increasing cross-referencing of courts and the transnational characteristics of IP and competition laws may be described-both descriptively and normatively - as an emerging global law of TRIPS flexibilities, based on screening and transparency. The reaction to the Covid-19 pandemic has the potential to accelerate this process. This is where other actors, including civil society and governments, through for instance patent oppositions, transparency of R\&D costs and limitation of anti-competitive abuses, play a crucial role.

\section{References}

Abbott FM, Correa CM, Drahos P (2012) Emerging markets and the World Patent Order. Edward Elgar, Cheltenham

Abdel-Latif A (15 April 2013) The Novartis decision: a tale of developing countries, IP, and the role of the judiciary, intellectual property watch, Available at https://www.ip-watch.org/2013/04/15/ the-novartis-decision-a-tale-of-developing-countries-ip-and-the-role-of-the-judiciary/ Ação Popular n. 1019631-97.2018.4.01.3400. Judgement on 23 September 2018

${ }^{109}$ Salomão Filho (2015).

${ }^{110}$ Salomão Filho (2015). 
Amsden A (2001) The rise of the rest: challenges to the West from late industrializing economies. Oxford University Press, Oxford

Ascarelli T (1970) Teoria della concurrencia y de los bienes inmateriales. Bosch, Madrid, p 276

Baker D, Jayadev A, Stiglitz (July 2017) Innovation, intellectual property and development: a better set of approaches for the 21st century, Available at: http://ip-unit.org/wp-content/uploads/2017/ 07/IP-for-21st-Century-EN.pdf

Bennett WJ (2014) Indian pharmaceutical patent law and the effects of Novartis Ag v. Union of India. Wash Univ Global Stud Law Rev 13:535. and its possible impacts

Bently L (2011) Exclusions from patentability and exceptions to patentees' right: taking exceptions seriously. Curr Legal Prob 64:315-347

Bermudez J, Prabhala A (13 May 2020) Gilead: o Brasil excluído no enfrentamento da pandemia, Available at: http://www.cee.fiocruz.br/?q=node/1176

Biehl J, Socal MP, Amon JJ (2016) The judicialization of health and the quest for state accountability: evidence from 1,262 lawsuits for access to medicines in Southern Brazil. Health Human Rights J 18(1)

Boldrin M, Levine DK (2013) The case against patents. J Econ Perspect 27(1):3-22

Bonilla Maldonado D (2013) Constitutionalism of the Global South: the activist tribunals of India, South Africa, and Colombia. Cambridge University Press, Cambridge

Borowski SM (2009) Saving tomorrow from today: preserving innovation in the face of compulsory licensing. Fla St Univ Law Rev 36. http://ir.law.fsu.edu/lr/vol36/iss2/6

Burk D, Lemley M (2013) The patent crisis and how the courts can solve it. University of Chicago Press, Chicago

Case n. 050277092320184025101, Federal Court of 2nd Region, Rio de Janeiro

Chang H-J (2002) Kicking away the ladder: development strategy in historical perspective. Anthem Press, London

Cimoli M, Dosi G, Maskus KE, Okediji RL, Reichman JH, Stiglitz JE (eds) (2014) Intellectual property rights: legal and economic challenges for development. Oxford University Press, Oxford

Competition Commission of India. Case No. 68 of 2016 - Roche - Mylan Biocon CCI Order 68 of 2016

Correa C (2016) Public health perspective on intellectual property and access to medicines, a compilation of studies prepared for WHO. South Centre, Geneva

Correa C, Velásquez G (2018) Acceso a Medicamentos: Experiencias com Licencias Obligatorias y Uso Gubernamental - el caso de la hepatitis C. Research Paper No. 85. South Centre, Geneva

Costa CG, Vieira MF, Renata R (2008) Access to medicines and intellectual property in Brazil: reflections and strategies of civil society. Revista Sur 8

Cueni T. Intellectual property is not a hindrance but a help to end Covid-19, Financial Times, available at: https://www.ft.com/content/e82dd07c-95c5-11ea-899a-f62a20d54625

Darling K, Perzanowski A (eds) (2017) Creativity without law: challenging the assumptions of intellectual property. NYU Press, New York

de Werra J (23 March 2016) Specialised intellectual property courts - issues and challenges. Published in: specialised intellectual property courts - issues and challenges, global perspectives for the intellectual property system, Issue Number 2: CEIPI-ICTSD. 2016, pp 15-41. Available at SSRN: https://ssrn.com/abstract=2761209

Deere C (2008) The implementation game: the TRIPS agreement and the global politics of intellectual property reform in developing countries. Oxford University Press, Oxford

Dezalay Y, Garth B (1996) Dealing in virtue: international commercial arbitration and the construction of a transnational legal order. University of Chicago Press, Chicago

DNDi (12 April 2018) New affordable hepatitis C combination treatment shows 97\% cure rate. DNDi, https://www.dndi.org/2018/media-centre/press-releases/new-affordable-hepatitis-c-com bination-treatment-shows-97-cure-rate/

Dreyfuss RC, Rodríguez-Gavarito C (2014) Balancing wealth and health: the battle over intellectual property and access to medicines in Latin America. Oxford University Press, Oxford 
European Commission Press Release. "Coronavirus Global Response: €7.4 billion raised for universal access to vaccines". 4 May 2020, available at: https://ec.europa.eu/commission/ presscorner/detail/en/ip_20_797

Fink C, Raffo J (2019) What role for intellectual property in industrial development. In: Correa C, Seuba X (eds) Intellectual property and development: understanding the interfaces. Springer, Berlin

Forbes (28 August 2019) Can Roche's blockbuster drug Herceptin's sales grow?, Available at: https://www.forbes.com/sites/greatspeculations/2019/08/28/can-roches-blockbuster-drugherceptins-sales-grow/\#62da696a42e5

Gabriela CC, Marcela V, da Costa Dorneles RF, Vianna MNS (2018) Medicamentos em situação de exclusividade financiados pelo Ministério da Saúde: Análise da Situação Patentária e das Compras Públicas. Fiocruz \& Escola Nacional de Saúde Pública Sergio, Arouca, pp 122-139

Gawel CR (2016) Patent protection as a key driver for pharmaceutical innovation. Pharm Policy Law 18:45-53, in Valverde, J.L.; Pisani, Eduardo, The Globalisation of the Pharmaceutical Industry, 2016

Geiger C, Nard CA, Seuba X (2018) Intellectual property and the judiciary. Edward Elgar, Cheltenham

Gilead (November 2017) Chronic hepatitis C treatment expansion - generic manufacturing for developing countries, Available at: https://www.gilead.com/-/media/files/pdfs/other/hcvgeneric-agreement-fast-facts-11-15-17.pdf

Grupo de Trabalho da Propriedade Intelectual (GTPI). Brazil is excluded from license authorizing production of generic medicine for hepatitis C. Available at: http://deolhonaspatentes.org/ media/file/GTPI_statement_Gilead_license_sofosbuvir.pdf

Grupo Direito e Pobreza (2019) Abuso de Direito Patentário e Prática de Preços Abusivos no Caso Hepatite C e Sofosbuvir

Grupo Direito e Pobreza (Law and Poverty Group) (10 June 2014) University of São Paulo. Representation to the Federal Public Ministry of Brazil against Roche

Hailbronner M (2017) Transformative constitutionalism: not only in the global South. Am J Comp Law 65(3):527-565

Hein W, Moon S (2013) Informal norms in global governance: human rights, intellectual property rules and access to medicines. Routledge, Milton Park

Heller M (2010) Gridlock economy: how too much ownership wrecks markets, stops innovation, and costs lives, Michael Heller. Basic Books, New York

Heller, Michael \& Eisenberg, Rebecca. Heller, M. A.; Eisenberg, R. (May 1998). Can patents deter innovation? The anticommons in biomedical research Science 280 (5364): 698-701

Hepatitis C cure (6 December 2018) Sofosbuvir, turns 5 years old: the vast majority of people still have not been treated, hepCoalition, https://hepcoalition.org/news/press-releases/article/ hepatitis-c-cure-sofosbuvir-turns-5-years-old-the-vast-majority-of-people-still?lang=en\#nb1

Hill A, Simmons B, Gotham D, Fortunak J (2016) Rapid reductions in prices for generic sofosbuvir and daclatasvir to treat hepatitis C. J Virus Erad 2(1):28-31

Hoen E (2019) Strong call for transparency on medicine prices, cost of R\&D at WHO fair pricing forum. Medicines Law and Policy. https://medicineslawandpolicy.org/2019/04/strong-call-fortransparency-on-medicine-prices-cost-of-rd-at-who-fair-pricing-forum/

Hu Y, Eynikel D, Boulet P et al (2020) Supplementary protection certificates and their impact on access to medicines in Europe: case studies of sofosbuvir, trastuzumab and imatinib. J Pharmaceutical Policy Practice 13:1

Inthira Y, Adun M, Sripen T, Chaisiri K, Yot T (2011) Government use licenses in Thailand: an assessment of the health and economic impacts. Global Health 7:28

Iyer V (2019) Constitution-making in Bhutan: a complex and Sui Generis experience. Chin J Comp Law 7(2):359-385

Juiz revoga liminar que quebrava patente de remédio contra hepatite C. https://www.jota.info/ paywall?redirect_to=//www.jota.info/tributos-e-empresas/saude/juiz-revoga-liminar-quequebrava-patente-de-remedio-contra-hepatite-c-21122018. LINK DOES NOT WORK 
Junqueira D (17 August 2019) Investigação do TCU aponta sobrepreço em remédio para câncer e leva a desabastecimento. Folha de São Paulo, Available at https://www1.folha.uol.com.br/ cotidiano/2019/08/investigacao-do-tcu-aponta-sobrepreco-em-remedio-para-cancer-e-leva-adesabastecimento.shtml

Kang HY (2020) Patents as assets: intellectual property rights as market subjects and objects. In: Birch K, Muniesa F (eds) Turning things into assets: new lineaments in the study of technoscientific capitalism. MIT Press, Cambridge

Kapczynski A (2017) Order without intellectual property law: open science in influenza. Cornell Law Rev 102:1539. Available at: https://scholarship.law.cornell.edu/clr/vol102/iss6/3

Kapczynski A (26 April 2019) The right to medicines in an age of neoliberalism. Humanity Journal, available at: http://humanityjournal.org/issue10-1/the-right-to-medicines-in-an-age-ofneoliberalism/

Karlin-Smith S (2020) How the drug industry got its way on the coronavirus. Politico, https://www. politico.com/news/2020/03/05/coronavirus-drug-industry-prices-122412

Kennedy D (1997) A critique of adjudication (fin de siècle). Harvard University Press, Cambridge

Knowledge Ecology International (KEI). CPTech's 2003 reports for the RSA Competition Commission, in Hazel Tau et al. v GSK, Boehringer, et al. Available at: https://www.keionline.org/ competition/2003-hazel-tau-tac

Lemos R, Castro O (2012) Tecnobrega. O Pará Reinventando o Negócio da Música (Tecnobrega. Pará reinventing the Music Business). Hunter Books, Nashville

Li X, Correa C (eds) (2009) Intellectual property enforcement - international perspectives. Edward Elgar \& South Centre, Northampton

Matthews D (2011) Intellectual property, human rights and development, the role of NGOs and social movements. Edward Elgar, Cheltenham

Matthews D, Gurgula O (12 May 2016) Patent strategies and competition law in the pharmaceutical sector: implications for access to medicines. Queen Mary School of Law Legal Studies Research Paper No. 233/2016. Available at SSRN: https://ssrn.com/abstract=2779014

Mazzucato M (2013) The entrepreneurial state: debunking public vs. private sector myths. Anthem Press, London

Mazzucato M, Torreele E (27 April 2020) How to develop a COVID-19 vaccine for all. project syndicate, Available at: https://www.project-syndicate.org/commentary/universal-free-covid19vaccine-by-mariana-mazzucato-and-els-torreele-2020-04

Mendes CH (2013) Constitutional courts and deliberative democracy, vol 1, 1st edn. Oxford University Press, Oxford, p 272

MSF Access Campaign Global day of action against Roche's inhumanity \#RocheGreedKills (6 February 2017) Press release, https://msfaccess.org/global-day-action-against-rochesinhumanity-rochegreedkills

Muir-Watt H (2016) Private international law beyond the Schism. Transnational Legal Theory 2, 2011(3):347-428

Muir-Watt H, Arroyo D, Bíziková L, de Oliveira AB (2019) Adjudication without frontiers: the global turn in private international law. Edward Elgar, London

Open Covid Pledge: https://opencovidpledge.org/

Pankhuri A, Shamnad B (13 August 2018) The morality of sexual pleasure: patent office training? Spicy IP, Available at: https://spicyip.com/2018/08/the-morality-of-sexual-pleasure-patentoffice-training.html

La Porta R, Lopez-de-Silanes F, Shleifer A, Vishny RW (1998) Law and finance. J Political Econ 106(6):1113-1155

Pottage A, Sherman B (2010) Figures of invention: a history of modern patent law. Oxford University Press, New York

Press Statement Minister of Health 20th September 2017 - Implementation of the Rights of Government for Sofosbuvir Tablet to Increase Access for Hepatitis C Treatment in Malaysia. Available at: https://kpkesihatan.com/2017/09/20/press-statement-minister-of-health-20th- 
september-2017-implementation-of-the-rights-of-government-for-sofosbuvir-tablet-toincrease-access-for-hepatitis-c-treatment-in-malaysia/

Report of the United Nations Secretary-General High-Level Panel on Access to Medicines (2016) Salomão Filho C (2007) Direito industrial, direito da concorrência e licenciamento compulsório. In: Basso M et al (eds) Direitos de Propriedade Intelectual \& Saúde Pública. O acesso universal aos medicamentos anti-retrovirais no Brasil. IDCID, São Paulo, pp 160-161

Salomão Filho C (2013a) A legal theory of economic power - implications for social and economic development. Edward Elgar, Cheltenham

Salomão Filho C (2013b) Direito Concorrencial. Malheiros, São Paulo, p 152

Salomão Filho C (2015) Teoria Crítico-Estruturalista do Direito Comercial. Marcial Pons, São Paulo

Salomão Filho C, Ido VHP (2019) Global corruption and economic power. In: Horatia MW, Diego A, Lucia B, de Oliveira AB (eds) Adjudication without frontiers: the global turn in private international law. Edward Elgar, London

Sanghera B (6 November 2015) Unmasking Central Asia's neoliberal judges. Open democracy, Available at: https://www.opendemocracy.net/en/odr/unmasking-central-asias-neoliberaljudges/

SBAC (2019) Medicamento contra hepatite C terá descontó para o governo. http://www.sbac.org. br/blog/2018/11/28/dona-de-patente-que-barra-generico-contra-hepatite-c-promete-desconto-agoverno/

Schiff E (1971) Industrialization without National Patents: the Netherlands, 1869-1912; Switzerland, 1850-1907. Princeton University Press, Princeton

Sell SK (2003) Private power, public law: the globalization of intellectual property rights. Cambridge University Press, Cambridge

Shadlen K (2017) Coalitions and compliance: the political economy of pharmaceutical patents in Latin America. Oxford University Press, Oxford

Silva M. Petição Inicial de Ação Popular (Statement of Claims of Popular Lawsuit)

Stiglitz J (19 October 2017) Wealth before health? Why intellectual property laws are facing a counterattack. The Guardian, available at: https://www.theguardian.com/business/2017/oct/18/ intellectual-property-laws-demand-a-21st-century-solution

Stiglitz J, Jayadev A (2010) Medicine for tomorrow: some alternative proposals to promote socially beneficial research and development in pharmaceuticals. J Generic Med 7(3):217-226

Syam N, Alas M, Ido VHP (2020) The 73rd World Health Assembly and resolution on COVID-19: quest of global solidarity for equitable access to health products. Policy Brief No. 78. South Centre, Geneva

Tambisetty S. Novartis v. Union of India and the Person Skilled in the Art: A Missed Opportunity. LSE Law, Society and Economy Working Papers 2/2014

United States Supreme Court (2013) Assoc. for Molecular Pathology v. Myriad Genetics, Inc., 569 U.S. 576 (on patentability of an isolated gene)

United States Trade Representative (USTR)'s Special 301 report of April 2020. Available at: https:// ustr.gov/sites/default/files/2020_Special_301_Report.pdf

Uprimny R (2011) The recent transformation of constitutional law in Latin America: trends and challenges. Texas Law Rev 89(7):1587-1609

Vanni A (2020) Patent games in the Global South: pharmaceutical patent law-making in Brazil, India and Nigeria. Bloomsbury, London

Velásquez G (2020) Rethinking R\&D for pharmaceutical products after the novel coronavirus COVID-19 shock. Policy Brief, No. 75. South Centre, Geneva

Velásquez G, Seuba X (2011) Rethinking global health: a binding convention for pharmaceutical products. Research Paper No. 42. South Centre, Geneva

Vieira M, Moon S (2019) Research synthesis: public funding of pharmaceutical R\&D. Graduate Institute, Global Health Centre, Geneva, available at: https://www.knowledgeportalia.org/ public-funding-of-r-d 
Vieira M, Moon S (2020) Research synthesis: costs of pharmaceutical R\&D. Graduate Institute, Global Health Centre, Geneva, available at https://www.knowledgeportalia.org/cost-of-r-d

Wang DWL (2015) Right to health litigation in Brazil: the problem and the institutional responses. Human Rights Law Rev 15:617

WHO COVID-19 Technology Access Pool (C-TAP): https://www.who.int/emergencies/diseases/ novel-coronavirus-2019/global-research-on-novel-coronavirus-2019-ncov/covid-19-technol ogy-access-pool

World Health Organization (2019) WHO model list of essential medicines, 21st List

Zumbansen P (2012) Transnational law, evolving. In: Smits J (ed) Encyclopedia of comparative law, 2nd edn. Edward Elgar, pp 899-925

Open Access This chapter is licensed under the terms of the Creative Commons Attribution 4.0 International License (http://creativecommons.org/licenses/by/4.0/), which permits use, sharing, adaptation, distribution and reproduction in any medium or format, as long as you give appropriate credit to the original author(s) and the source, provide a link to the Creative Commons license and indicate if changes were made.

The images or other third party material in this chapter are included in the chapter's Creative Commons license, unless indicated otherwise in a credit line to the material. If material is not included in the chapter's Creative Commons license and your intended use is not permitted by statutory regulation or exceeds the permitted use, you will need to obtain permission directly from the copyright holder. 